\title{
Emergence of a negative activation heat capacity during evolution of a designed enzyme
}

\author{
H. Adrian Bunzel ${ }^{\dagger}$, Hajo Kries ${ }^{\dagger}$, Luca Marchetti ${ }^{\dagger}$, Cathleen Zeymer ${ }^{\dagger}$, Peer R. E. Mittl ${ }^{\ddagger}$, \\ Adrian J. Mulholland ${ }^{\S}$, Donald Hilvert ${ }^{\dagger *}$
}
$\dagger^{\dagger}$ Laboratory of Organic Chemistry, ETH Zurich, 8093 Zurich, Switzerland
¥Department of Biochemistry, University of Zurich, 8057 Zurich, Switzerland
$\S$ Centre of Computational Chemistry, School of Chemistry, University of Bristol, BS8 1TS Bristol, United Kingdom

*hilvert@org.chem.ethz.ch

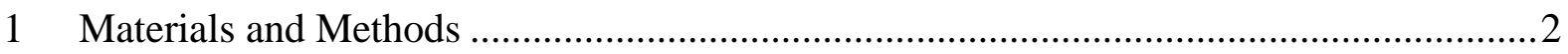

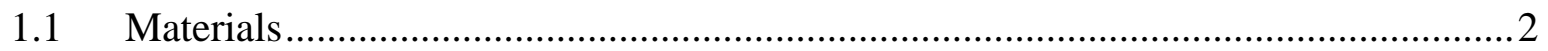

$1.2 \quad$ Directed evolution of Kemp eliminase 1A53-2 ….............................................

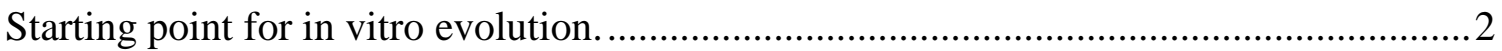

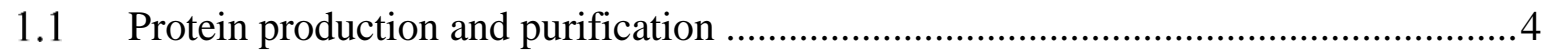

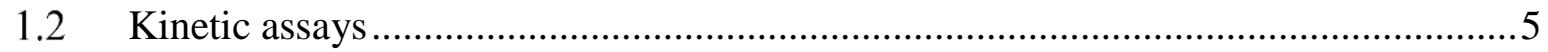

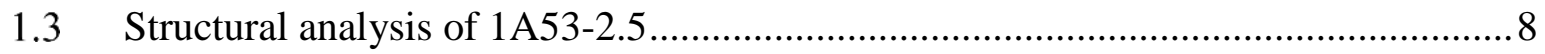

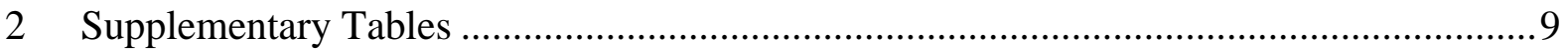

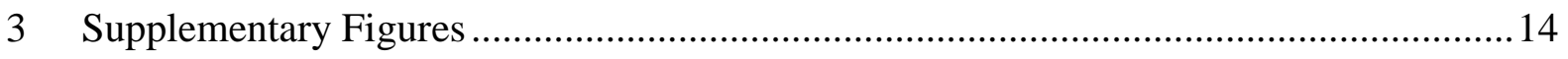

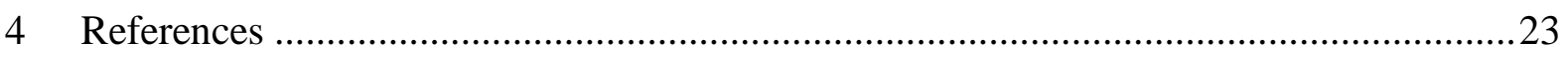




\section{Materials and Methods}

\subsection{Materials}

6-Nitrobenzisoxazole and 5-nitrobenzisoxazole were synthesized from the respective salicylaldehyde by first forming an oxime and then cyclizing with $\mathrm{PPh}_{3}$ and DDQ according to published procedures. ${ }^{1}$

\subsection{Directed evolution of Kemp eliminase 1A53-2}

Starting point for in vitro evolution. Kemp eliminase 1A53-2 was previously designed by Privett et al. using the thermostable indole-3-glycerolphosphate synthase from Sulfolobus solfataricus (PDB: 1A53) as a scaffold. ${ }^{2,3}$ We employed the resulting enzyme as the starting point for multiple rounds of directed evolution via iterative rounds of saturation mutagenesis, error-prone PCR and DNA shuffling, combined with microtiter plate screening.

Library construction. Libraries were constructed by overlap-extension PCR with Phusion polymerase (Finnzymes). Fragments were constructed with the primers listed in Table S4 and either the forward AKZ3 (TAATACGACTCACTATAGGG) or reverse T7term (GCTAGTTATTGCTCAGCGG) primer. For a typical PCR protocol, samples were incubated 5 min at $98{ }^{\circ} \mathrm{C}$ and the DNA was amplified over 32 cycles between $98{ }^{\circ} \mathrm{C}(30 \mathrm{~s}), 55^{\circ} \mathrm{C}(30 \mathrm{~s})$ and $72{ }^{\circ} \mathrm{C}(30 \mathrm{~s})$. After a final elongation for $5 \mathrm{~min}$ at $72{ }^{\circ} \mathrm{C}$, the samples were cooled to $4{ }^{\circ} \mathrm{C}$. The fragments were purified by agarose gel electrophoresis using gels with $2 \%$ agarose in $0.5 \mathrm{~g} / \mathrm{L}$ sodium borate $\left(\mathrm{Na}_{2} \mathrm{~B}_{4} \mathrm{O}_{7} \times 10 \mathrm{H}_{2} \mathrm{O}\right)$. Gels were stained with ez-vision one (Amresco). Gel electrophoresis was performed at $200 \mathrm{~V}$ for $20 \mathrm{~min}$ at a variable electrical current. DNA extractions from agarose gels were carried out using the Zymoclean Gel DNA Recovery Kit (Zymo Research). Fragments were assembled by PCR using a similar protocol as described above. During PCR, 15 cycles were performed without the T7 and T7term primers to assemble the genes and 32 cycles were performed thereafter with the outer primer for amplification. PCR products were purified via agarose gel electrophoresis (1\% agarose) as described above. The assembled genes were amplified by PCR, purified with the DNA Clean \& Concentrator kit (Zymo research) and cloned into pET11 for screening. To this end, plasmids were purified with the Zyppy Plasmid Miniprep Kit (Zymo research) from E. coli X11-Blue cells. For cloning, 2 $\mu \mathrm{g}$ of pet11 vector and $1 \mu \mathrm{g}$ of insert were digested with NdeI and BamHI (New England Biolabs). Vector and insert were purified via agarose gel electrophoresis (1\% agarose) as described above. Fragments were ligated using T4 DNA ligase (New England Biolabs) and purified with the DNA Clean \& Concentrator kit (Zymo Research). Electro-competent E. coli Xl1 Blue cells were transformed with the library, ${ }^{4}$ transferred to $10 \mathrm{~mL} \mathrm{LB}$ and incubated for 
$1 \mathrm{~h}$ at $37^{\circ} \mathrm{C}$ and $230 \mathrm{rpm}$. After $1 \mathrm{~h}, 0.1 \%$ of the culture was transferred onto an LB-agar plate (100 $\mu \mathrm{g} / \mathrm{mL}$ ampicillin) for estimation of the library size. Ampicillin $(100 \mu \mathrm{g} / \mathrm{mL})$ was added to the culture and the culture was incubated overnight at $37^{\circ} \mathrm{C}$ and $230 \mathrm{rpm}$. The library was ready for screening after purification with the Zyppy Plasmid Miniprep Kit (Zymo research). All DNA concentrations were determined on a NanoDrop spectrophotometer (ThermoFischer). Gene sequences were confirmed by DNA sequencing (Microsynth).

Active site optimization: Rounds 1-5. In the first five rounds of laboratory evolution, 20 firstshell active site residues were individually subjected to saturation mutagenesis using NNK codons. The best resulting variants were subsequently combined by DNA shuffling via overlapextension PCR. ${ }^{5}$ In round 1 , residues in close proximity to the general base Glu178 (residues $53,58,157,159,180,182$ and 211) were targeted, and the identified hits were shuffled in round 2. In round 3, the remaining first-shell residues (residues 51, 56, 60, 81, 83, 89, 108, 110, 131, 184 and 210) were mutagenized and the identified hits shuffled in round 4. In round 5, all 20 active site residues were again individually revisited by saturation mutagenesis. Cloning was performed as described above.

Global optimization: Rounds 6-9. After active site optimization was complete, the complete scaffold was targeted in alternating rounds of error-prone PCR and DNA shuffling (rounds 68). In rounds 8 and 9, shuffling and error-prone PCR were performed simultaneously in one round. The template for cloning the error-prone PCR libraries was prepared by PCR with phusion from a pet11 plasmid harboring the hits. Randomization was performed using Mutazyme II (Agilent). $1 \mathrm{ng}$ of the template was subjected to 32 cycles of amplification. After purification using the DNA Clean \& Concentrator kit, the insert was amplified via PCR and cloning was continued as previously described.

Library screening. In order to guarantee approximately 3 -fold oversampling, 100 clones were screened per saturation mutagenesis library. ${ }^{6}$ For the error-prone PCR and DNA shuffling libraries, 800 to 1000 clones were screened. Adequate coverage was ensured by restricting library sizes to either an average of one mutation per gene or fewer than 1000 different possible combinations. BL21-Gold(DE3) cells were transformed with the gene libraries and plated on LB agar plates (containing $100 \mu \mathrm{g} / \mathrm{mL}$ ampicillin). Single colonies were used to inoculate $600 \mu \mathrm{L} \mathrm{LB}$ medium (containing $100 \mu \mathrm{g} / \mathrm{mL}$ ampicillin) in a 96-well deepwell plate. After overnight incubation at $30{ }^{\circ} \mathrm{C}$ with shaking, $200 \mu \mathrm{L}$ cultures were stored in replica plates. The remainder of the culture was induced by addition of LB (containing $1 \mathrm{mM} \mathrm{IPTG,} 100 \mu \mathrm{g} / \mathrm{mL}$ 
ampicillin) to a final volume of $1.6 \mathrm{~mL}$. The temperature was reduced to $18{ }^{\circ} \mathrm{C}$ and protein production continued for $18 \mathrm{~h}$. Catalytic efficiency was assayed after appropriate dilution $(1: 10$ to $1: 1,000)$ into assay buffer (50 mM phosphate, $100 \mathrm{mM} \mathrm{NaCl}, 10 \%$ methanol, $\mathrm{pH} 7.0$ ) containing $500 \mu \mathrm{M}$ 6-nitrobenzisoxazole at $400 \mathrm{~nm}$ in a plate reader (Molecular Devices). Activity of the most active clones was confirmed by rescreening in triplicates. Colonies with the largest increase in activity relative to the preceding round were regrown for plasmid isolation, sequencing, and further diversification. For rounds 1 and 2, cells were lysed prior to the activity assay due to the low activity of the initial design. Cells were harvested by centrifugation and the supernatant was discarded. The cell pellets were frozen at $-80{ }^{\circ} \mathrm{C}$ for $2 \mathrm{~h}$ and thawed at room temperature. In total, three freeze and thaw cycles were performed for cell lysis. After the final thaw, the cells were resuspended in $300 \mu \mathrm{L}$ lysis buffer $(50 \mathrm{mM}$ sodium phosphate, $100 \mathrm{mM} \mathrm{NaCl}, 1 \mathrm{mg} / \mathrm{mL}$ lysozyme, DNaseI, pH 8.0) and incubated for $1 \mathrm{~h}$ at room temperature before clearing the lysates by centrifugation. The activity in the lysate was assayed at $\mathrm{pH} 8.0$ as described above.

\subsection{Protein production and purification}

BL21-Gold(DE3) cells were transformed with the pET11 plasmid harboring the gene of interest and plated on LB agar plates (with $100 \mu \mathrm{g} / \mathrm{mL}$ ampicillin). A single colony was used to inoculate an overnight culture of LB medium containing $100 \mu \mathrm{g} / \mathrm{mL}$ ampicillin. $500 \mathrm{~mL}$ of LB medium containing $100 \mu \mathrm{g} / \mathrm{mL}$ ampicillin were inoculated with the overnight culture in a ratio of 1:100 and grown to an $\mathrm{OD}_{600}$ of 0.5 at $37^{\circ} \mathrm{C}$. Protein production was induced with $1 \mathrm{mM}$ IPTG, and cells were incubated at $18{ }^{\circ} \mathrm{C}$ overnight. The cells were harvested and the cell pellet was either frozen at $-80{ }^{\circ} \mathrm{C}$ or directly processed for protein purification. The cell pellet was resuspended in lysis buffer $(20 \mathrm{~mL} 50 \mathrm{mM}$ Tris- $\mathrm{HCl} \mathrm{pH} 7.4$, containing $0.5 \mathrm{M} \mathrm{NaCl}$, $10 \mathrm{mM}$ imidazole, $100 \mu \mathrm{L}$ protease inhibitor cocktail (Sigma), $1 \mathrm{mg} / \mathrm{mL}$ lysozyme and DNaseI). The cell suspension was sonicated for $1 \mathrm{~h}$ in a sonication bath at $4{ }^{\circ} \mathrm{C}$ (Telesonic Ultrasonics). After centrifugation $\left(18,000 \mathrm{rpm}, 20 \mathrm{~min}, 4{ }^{\circ} \mathrm{C}\right)$, the soluble fraction was applied to a $3 \mathrm{~mL}$ Ni-NTA slurry (Qiagen), washed with $10 \mathrm{mM}$ imidazole before elution of the protein with $300 \mathrm{mM}$ imidazole, each in $50 \mathrm{mM}$ Tris- $\mathrm{HCl}, 0.5 \mathrm{M} \mathrm{NaCl}, \mathrm{pH}$ 8.0. The buffer was exchanged to $20 \mathrm{mM}$ sodium phosphate, $20 \mathrm{mM} \mathrm{NaCl}, \mathrm{pH} 6.0$ by washing three times in an Amicon Ultra-15 unit with a $10 \mathrm{kDa}$ molecular cut-off (Millipore). Proteins were further purified by cation exchange chromatography (MonoS column, GE Healthcare) and eluted with a salt gradient (20 mM to $1 \mathrm{M} \mathrm{NaCl}, 20 \mathrm{mM}$ sodium phosphate, $\mathrm{pH}$ 6.0). Fractions absorbing at $280 \mathrm{~nm}$ were analyzed by SDS-PAGE (Phastsystem, Pharmacia Biotech) using a low 
molecular weight marker (GE Healthcare). Fractions containing the target protein were pooled and concentrated using an Amicon Ultra-15 unit with a $10 \mathrm{kDa}$ molecular cut-off (Millipore) if necessary. Protein concentrations were determined by measuring the absorbance at $280 \mathrm{~nm}$ and a calculated extinction coefficient. ${ }^{7}$ The following extinction coefficients were determined for representative enzymes: $\varepsilon(1 \mathrm{~A} 53-2)=29,910 \mathrm{M}^{-1} \mathrm{~cm}^{-1} ; \quad \varepsilon(1 \mathrm{~A} 53-2.5)=31,400 \mathrm{M}^{-1} \mathrm{~cm}^{-1}$; $\varepsilon(1 \mathrm{~A} 53-2.10)=31,400 \mathrm{M}^{-1} \mathrm{~cm}^{-1}$. Protein masses were confirmed by mass spectrometry. For mass determination, the buffer was exchanged into $0.1 \%$ acetic acid with Vivaspin 500 centrifugal filters (Sartorius) and measured by ESI-MS on a Daltonics maXis ESI-Q-TOF mass spectrometer (Bruker). Mass spectra were deconvoluted using the MaxEnt1 software. All masses corresponded to the expected sequence lacking the N-terminal methionine.

\subsection{Kinetic assays}

Michaelis-Menten kinetics. Reactions were initiated by adding enzyme (10 $\mathrm{nM}$ to $10 \mu \mathrm{M})$ to the benzisoxazole substrate $(100 \mu \mathrm{M}$ to $1.5 \mathrm{mM}$ final concentration) in $50 \mathrm{mM}$ sodium phosphate, $100 \mathrm{mM} \mathrm{NaCl}, 100 \mu \mathrm{M}$ TCEP, $10 \%$ methanol $\left(\mathrm{pH} \mathrm{7.0)}\right.$ at $25^{\circ} \mathrm{C}$. The $\mathrm{pH}$ of the buffer was measured after addition of $10 \%$ methanol using a SenTix $81 \mathrm{pH}$ electrode (Gerber Instruments). Product formation was monitored at $400 \mathrm{~nm}$ for 6-nitrobenzisoxazole $\left(\varepsilon_{400}=2,870 \mathrm{M}^{-1} \mathrm{~cm}^{-1}\right)$ and at $380 \mathrm{~nm}$ for 5-nitrobenzisoxazole $\left.\varepsilon_{380}=15,800 \mathrm{M}^{-1} \mathrm{~cm}^{-1}\right)$ in a Lambda $35 \mathrm{UV} /$ Vis spectrometer (PerkinElmer) at $25{ }^{\circ} \mathrm{C} .{ }^{8}$ The slope before addition of protein was subtracted as background. Initial rates divided by the catalyst concentration were plotted against substrate concentration, and $k_{\text {cat }}$ and $K_{\mathrm{M}}$ values were determined by fitting the data to the Michaelis-Menten equation:

$$
\frac{\mathrm{v}_{0}}{[\mathrm{E}]_{0}}=\frac{k_{\mathrm{cat}} \cdot[\mathrm{S}]}{K_{\mathrm{M}}+[\mathrm{S}]}
$$

pH-rate profiles. The $\mathrm{pH}$ dependence of $k_{\mathrm{ca}} / K_{\mathrm{M}}$ was determined by measuring initial rates at $100 \mu \mathrm{M}$ 6-nitrobenzisoxazole in $50 \mathrm{mM}$ BTP, $50 \mathrm{mM}$ phosphate, $100 \mathrm{mM}$ sodium chloride, $100 \mu \mathrm{M}$ TCEP, $10 \%$ methanol at $25^{\circ} \mathrm{C}$. The enzymes were preincubated in the assay buffer for at least $5 \mathrm{~min}$ prior to initiation of the reaction by substrate addition. Product formation was monitored as described above. The rate of the uncatalyzed reaction was measured with an identical sample without enzyme and subtracted. The apparent extinction coefficient for 6-nitro-2-hydroxybenzonitrile at $400 \mathrm{~nm}$ was corrected for the ionization state of the product using Equation 2, 


$$
\Delta \varepsilon=\frac{\Delta \varepsilon_{\max }}{1+10^{\mathrm{p} K_{\mathrm{a}}-\mathrm{pH}}}
$$

where $\Delta \varepsilon_{\max }=2870 \mathrm{M}^{-1} \mathrm{~cm}^{-1}$ and $\mathrm{p} K_{\mathrm{a}}=5.2$. The bell-shaped $\mathrm{pH}$-rate profiles were fitted to Equation 3 to determine the apparent ionization constants $\mathrm{p} K_{\mathrm{a}, 1}$ and $\mathrm{p} K_{\mathrm{a}, 2}$ :

$$
\left(\frac{k_{\mathrm{cat}}}{K_{\mathrm{M}}}\right)=\frac{\left(\frac{k_{\mathrm{cat}}}{K_{\mathrm{M}}}\right)_{\max }}{1+10^{\mathrm{p} K_{\mathrm{a}, 1}-\mathrm{pH}}+10^{\mathrm{pH}-\mathrm{p} K_{\mathrm{a}, 2}}}
$$

$\boldsymbol{K}_{\mathbf{i}}$ determination. The enzymes $(10 \mathrm{nM}$ to $10 \mu \mathrm{M})$ were incubated for at least $5 \mathrm{~min}$ in buffer containing up to $1 \mathrm{mM}$ 6-nitrobenzotriazole in $50 \mathrm{mM}$ sodium phosphate, $100 \mathrm{mM} \mathrm{NaCl}$, $100 \mu \mathrm{M}$ TCEP, $1 \%$ DMSO $(\mathrm{pH} 7.0)$ at $25^{\circ} \mathrm{C}$. Reactions were initiated by addition of 6-nitrobenzisoxazole in methanol to a final concentration of $100 \mu \mathrm{M}$ and $10 \%$ methanol. Product formation was monitored as described previously. The $K_{\mathrm{i}}$ values were determined by fitting the data to the following equation.

$$
\left(\frac{k_{\mathrm{cat}}}{K_{\mathrm{M}}}\right)=\frac{\left(\frac{k_{\mathrm{cat}}}{K_{\mathrm{M}}}\right)_{\max }}{1+10^{\left(\log (\mathrm{c}(\text { inhibitor }))-\log \left(K_{\mathrm{i}}\right)\right)}}
$$

Total turnover analysis. Enzyme $(50 \mathrm{nM})$ was added to $990 \mu \mathrm{L}$ buffer containing $100 \mu \mathrm{M}$ 6-nitrobenzisoxazole in $50 \mathrm{mM}$ sodium phosphate at pH 7.0 with $100 \mathrm{mM} \mathrm{NaCl}, 100 \mu \mathrm{M}$ TCEP, 9\% methanol (pH 7.0) at $25^{\circ} \mathrm{C}$. After $40 \mathrm{~min}, 10 \mu \mathrm{L} 10 \mathrm{mM}$ 6-nitrobenzisoxazole in methanol were added. Product formation was monitored as described above. The background reaction rate was corrected as follows. First, a similar sample without enzyme was assayed. The background rate constant, $k_{\text {background, }}$ was calculated by dividing the initial velocity by the substrate concentration. The amount of substrate present at each time point during the enzymecatalyzed reaction was calculated based on the measured absorbance of the product formed. The amount of product formed in the background reaction was determined by multiplication of $k_{\text {background }}$ by the calculated substrate concentration at each time point. Subtraction of the product formed by the background reaction from the total amount of product afforded the background corrected curve plotted in Figure S4F. The product formed in the background reaction corresponded to $2-4 \mu \mathrm{M}$, and consequently had only a negligible effect on the total amount of product formed by the enzyme. The total turnover number was derived by dividing the total amount of product formed by the enzyme concentration. 
Uncatalyzed and acetate-promoted reactions. The rate constant for the uncatalyzed reaction $\left(k_{\text {uncat }}\right)$ and acetate-promoted deprotonation $\left(k_{\mathrm{AcO}-}\right)$ were determined by measuring initial rates as previously described at $100 \mu \mathrm{M}$ 6-nitrobenzisoxazole in 100-600 mM sodium acetate, $100 \mathrm{mM} \mathrm{NaCl}, 10 \%$ methanol (pH 7.0). $k_{\mathrm{AcO}}$ - was determined from the slope and $k_{\text {uncat }}$ from the intercept of the rate vs. acetate plot.

Arrhenius analysis. The temperature dependence of $k_{\mathrm{cat}} / K_{\mathrm{M}}$ was determined by measuring initial rates at $30 \mu \mathrm{M}$ 6-nitrobenzisoxazole in $50 \mathrm{mM}$ sodium phosphate $100 \mathrm{mM} \mathrm{NaCl}$, $100 \mu \mathrm{M}$ TCEP, $10 \%$ methanol (pH 7.0). Since the substrate concentration is at least 5 fold below the lowest measured $K_{\mathrm{M}}, k_{\mathrm{ca}} / K_{\mathrm{M}}$ can be directly determined from the initial slopes. Moreover, the highest enzyme concentration ( $4 \mu \mathrm{M}$ for 1A53-2) is well below the substrate concentration, ensuring standard Michaelis-Menten conditions. The enzymes were preincubated in the assay buffer for at least $5 \mathrm{~min}$ at temperatures ranging between $5{ }^{\circ} \mathrm{C}$ and $55{ }^{\circ} \mathrm{C}$ prior to initiating the reaction by substrate addition. Product formation was monitored as previously described. The thermodynamic activation parameters $\Delta \mathrm{H}^{\ddagger}$ and $\Delta \mathrm{S}^{\ddagger}$ for $1 \mathrm{~A} 53-2$ were obtained by fitting the data to the standard Eyring equation ${ }^{9}$ (5). For the evolved variants for 1A53-2 .5 and 1A53-2.9, the data were fitted to equation (6).

$$
\begin{gathered}
\ln \left(\frac{k_{\text {cat }}}{K_{\mathrm{M}}}\right)=\ln \left(\frac{k_{\mathrm{B}} \mathrm{T}}{\mathrm{h}}\right)-\frac{\Delta \mathrm{H}^{\ddagger}}{\mathrm{RT}}+\frac{\Delta \mathrm{S}^{\ddagger}}{\mathrm{R}} \\
\ln \left(\frac{k_{\mathrm{cat}}}{K_{\mathrm{M}}}\right)=\ln \left(\frac{k_{\mathrm{B}} \mathrm{T}}{\mathrm{h}}\right)-\frac{\left[\Delta \mathrm{H}_{\mathrm{T} 0}^{\ddagger}+\Delta \mathrm{C}_{\mathrm{p}}^{\ddagger}\left(\mathrm{T}+\mathrm{T}_{0}\right)\right]}{\mathrm{RT}}+\frac{\left[\Delta \mathrm{S}_{\mathrm{T} 0}^{\ddagger}+\Delta \mathrm{C}_{\mathrm{p}}^{\ddagger} \ln \left(\mathrm{T} / \mathrm{T}_{0}\right)\right]}{\mathrm{R}}
\end{gathered}
$$

For the acetate-promoted reaction, $k_{\mathrm{AcO}-}$ was determined from reactions of 300, 600 and $900 \mathrm{mM}$ sodium acetate in the same buffer at varying temperatures. The thermodynamic parameters were calculated using equation (5).

Circular dichroism spectroscopy. The far-ultraviolet spectrum of protein samples $(5 \mu \mathrm{M})$ was measured in $50 \mathrm{mM}$ sodium phosphate buffer, $\mathrm{pH} 7.0$, and $100 \mathrm{mM} \mathrm{NaCl}$ at $20{ }^{\circ} \mathrm{C}$ using an Aviv 202 spectropolarimeter (Aviv Associates). Thermal denaturation of the protein $(5 \mu \mathrm{M})$ was monitored at $225 \mathrm{~nm}$ from $25^{\circ} \mathrm{C}$ to $95{ }^{\circ} \mathrm{C}$ with $1{ }^{\circ} \mathrm{C}$ steps, an equilibration time of $30 \mathrm{~s}$ and an averaging time of $3 \mathrm{~s}$. 


\subsection{Structural analysis of 1A53-2.5}

Crystallization. Proteins were crystallized in the presence of the inhibitor 6-nitrobenzotriazole. A stock solution of the inhibitor in DMSO (final concentration inhibitor in the enzyme solution $1 \mathrm{mM}$ ) was added to $100 \mu \mathrm{M}$ protein in $20 \mathrm{mM}$ phosphate, $20 \mathrm{mM}$ sodium chloride, $\mathrm{pH}$ 6.0, to a final DMSO concentration of $0.1 \%$ DMSO. Crystals were grown at $20{ }^{\circ} \mathrm{C}$ in hanging drops using the vapor diffusion technique (3-Well Crystallization Plates, Jena Bioscience). After an initial screen, the best condition (300 nL enzyme, $100 \mathrm{~nL}$ mother liquor (0.1 M sodium citrate, $20 \mathrm{mM}$ sodium sulfate, 40\% v/v PEG 300, $\mathrm{pH} 4.2)$ ) was refined by varying the $\mathrm{pH}$ and PEG concentration. The best crystals were obtained with $400 \mathrm{~nL}$ enzyme in $100 \mathrm{~nL}$ mother liquor containing $0.1 \mathrm{M}$ sodium citrate, $20 \mathrm{mM}$ sodium sulfate, $43 \% \mathrm{v} / \mathrm{v}$ PEG 300, $\mathrm{pH}$ 5.6. These crystals were ground and used as seed stocks. The final crystals were obtained by repeating the refinement screen in the presence of $50 \mathrm{~nL}$ seed stock.

Data collection and analysis. X-ray diffraction data sets were collected on the X06SA beamline at the Swiss Light Source (Paul Scherrer Institute) using an EIGER X 16M detector. A wavelength of $1.0000 \AA$ was used for data collection. The diffraction data were processed and scaled using the XDS program package. ${ }^{10}$ The initial phases were determined by molecular replacement, using the structure of Kemp eliminase 1A53-2 (PDB code: $3 \mathrm{NZ1})^{2}$ as a search model. Molecular replacement was performed with Phaser. ${ }^{11}$ The structure was modified manually with Coot and refined with Phenix ${ }^{12,13}$ and Buster. ${ }^{14}$ The final crystal data and intensity statistics are summarized in Table S5. Structure factors and coordinates have been deposited at the PDB with the entry code 6NW4 and raw diffraction data have been deposited at http://proteindiffraction.org. 


\section{Supplementary Tables}

Table S1. Kinetic and thermodynamic parameters for Kemp eliminase 1A53-2 variants ${ }^{\text {a }}$

\begin{tabular}{|c|c|c|c|}
\hline & 1A53-2 & 1A53-2.5 & 1A53-2.9 \\
\hline $\begin{array}{l}k_{\text {cat }} \\
\left(\mathrm{s}^{-1}\right)\end{array}$ & $0.0058 \pm 0.0008$ & $10 \pm 1$ & $24 \pm 2$ \\
\hline $\begin{array}{c}K_{M} \\
(\mu M)\end{array}$ & $1200 \pm 300$ & $710 \pm 130$ & $590 \pm 80$ \\
\hline $\begin{array}{l}k_{\text {cat }} / K_{\mathbf{M}} \\
\left(\mathbf{M}^{-1} \mathbf{s}^{-1}\right)\end{array}$ & $3.9 \pm 1.4$ & $12000 \pm 2800$ & $40900 \pm 5800$ \\
\hline $\boldsymbol{k}_{\text {cat }} / \boldsymbol{k}_{\text {uncat }}$ & $(1.10 \pm 0.2) \times 10^{4}$ & $(1.9 \pm 0.2) \times 10^{7}$ & $(4.2 \pm 0.4) \times 10^{7}$ \\
\hline $\begin{array}{l}1 / K_{\mathrm{TS}} \\
\left(\mathbf{M}^{-1}\right)^{\mathrm{d}}\end{array}$ & $(9.4 \pm 1.2) \times 10^{6}$ & $(2.7 \pm 0.4) \times 10^{10}$ & $(7.8 \pm 1.6) \times 10^{10}$ \\
\hline$\left(k_{\mathrm{cat}} / K_{\mathrm{M}}\right) / k_{\mathrm{AcO}-}{ }^{\mathrm{b}}$ & $(6.7 \pm 1.9) \times 10^{5}$ & $(1.9 \pm 0.4) \times 10^{9}$ & $(5.5 \pm 0.8) \times 10^{9}$ \\
\hline specificity $f$ & 0.5 & 100 & 120 \\
\hline $\begin{array}{c}K_{\mathbf{I}} \\
(\mu \mathrm{M}) \mathrm{g}\end{array}$ & $1.8 \pm 0.2$ & $0.46 \pm 0.07$ & $0.23 \pm 0.02$ \\
\hline $\mathbf{p} K_{\mathrm{a}, 1}{ }^{\mathrm{c}}$ & $8.7 \pm 0.3$ & $5.4 \pm 0.1$ & $5.4 \pm 0.1$ \\
\hline $\mathrm{p} K_{\mathrm{a}, 2}{ }^{\mathrm{c}}$ & $9.4 \pm 0.3$ & $8.7 \pm 0.1$ & $9.2 \pm 0.1$ \\
\hline $\begin{array}{c}\Delta \mathbf{H}_{\mathrm{T}_{0}}^{\ddagger} \\
\left(\mathrm{kcal}^{\left.\mathbf{m} \mathbf{m o l}^{-1}\right)^{\mathrm{e}}}\right.\end{array}$ & $19.4 \pm 0.9$ & $7.0 \pm 0.2$ & $5.2 \pm 0.2$ \\
\hline $\begin{array}{c}\Delta \mathbf{S}_{\mathrm{T}_{0}}^{\ddagger} \\
\left(\text { cal } \mathrm{mol}^{-1} \mathbf{K}^{-1}\right)^{\mathrm{e}}\end{array}$ & $9.2 \pm 2.9$ & $-16.6 \pm 0.6$ & $-21.0 \pm 0.8$ \\
\hline $\begin{array}{c}\Delta \mathbf{C}_{\mathbf{p}}^{\ddagger} \\
\left(\mathrm{kcal}^{-1} \mathrm{~mol}^{-1} \mathbf{K}^{-1}\right)^{\mathrm{e}}\end{array}$ & n.a. & $-0.28 \pm 0.02$ & $-0.29 \pm 0.03$ \\
\hline $\begin{array}{c}\Delta \mathbf{G}_{\mathrm{T}_{0}}^{\ddagger} \\
\left(\text { kcal mol}^{-1}\right)^{\mathrm{e}}\end{array}$ & $16.6 \pm 1.2$ & $12.0 \pm 0.2$ & $11.4 \pm 0.2$ \\
\hline $\begin{array}{l}\mathbf{T}_{\text {opt }} \\
(\mathbf{K})^{h}\end{array}$ & n.a. & $323.6 \pm 1.9$ & $315.9 \pm 1.9$ \\
\hline $\begin{array}{l}\mathbf{T}_{\mathbf{M}} \\
(\mathbf{K})\end{array}$ & $347.9 \pm 0.4$ & $355.6 \pm 0.9$ & $336.7 \pm 0.4$ \\
\hline
\end{tabular}

${ }^{a}$ Measured at $25{ }^{\circ} \mathrm{C}$ in $50 \mathrm{mM}$ phosphate, $100 \mathrm{mM} \mathrm{NaCl}, 100 \mu \mathrm{M}$ TCEP, $10 \%$ methanol, pH 7.0 for 6-nitrobenzisoxazole, if not otherwise stated. The estimated errors reflect the standard deviations of two to six independent measurements.

${ }^{\mathrm{b}} \mathrm{A} k_{\text {uncat }}$ of $(5.3 \pm 0.6) \times 10^{-7} \mathrm{~s}^{-1}$ was determined for the uncatalyzed and a $k_{\text {AcO- }}$ of $(7.4 \pm 0.2) \times 10^{-6}$ $\mathrm{M}^{-1} \mathrm{~s}^{-1}$ for the acetate promoted cleavage of 6-nitrobenzisoxazole.

${ }^{\mathrm{c}} \mathrm{p} K_{\mathrm{a}, 1}$ and $\mathrm{p} K_{\mathrm{a}, 2}$ refer to the two apparent inflections in the bell-shaped $\mathrm{pH}$-rate profiles.

${ }^{\mathrm{d}}$ Chemical proficiency is defined as: $1 / K_{\mathrm{TS}}=k_{\text {cat }} / K_{\mathrm{M}} / k_{\text {uncat. }}{ }^{15}$

${ }^{\mathrm{e}}$ The thermodynamic parameters are reported for $25^{\circ} \mathrm{C}$. The activation parameters for the acetatepromoted Kemp elimination of 6-nitrobenzisoxazole are $\Delta \mathrm{H}_{\mathrm{T}_{0}}^{\ddagger}=25.9 \pm 1.3 \mathrm{kcal} / \mathrm{mol}, \quad \Delta \mathrm{S}_{\mathrm{T}_{0}}^{\ddagger}$ $=4.7 \pm 4.3 \mathrm{cal} \mathrm{mol}^{-1} \mathrm{~K}^{-1}, \Delta \mathrm{G}_{\mathrm{T}_{0}}^{\ddagger}=24.5 \pm 0.1 \mathrm{kcal} / \mathrm{mol}$.

${ }^{\mathrm{f}}$ Specificity is defined as the ratio of the apparent second-order rate constant for 6-nitrobenzisoxazole and 5-nitrobenzisoxazole: $\left(k_{\text {cat }} / K_{\mathrm{M}}\right)_{6 \text {-nitrobenzisoxazole }} /\left(k_{\text {cat }} / K_{\mathrm{M}}\right)_{5 \text {-nitrobenzisoxazole. }}$

${ }^{\mathrm{g}}$ Inhibition constant for 5-nitrobenzotriazole

${ }^{\mathrm{h}}$ The optimal temperature was calculated based on $\mathrm{T}_{\mathrm{opt}} \approx \mathrm{T}_{0}-\Delta \mathrm{H}_{\mathrm{T}_{0}}^{\ddagger} / \Delta \mathrm{C}_{\mathrm{p}}^{\ddagger}{ }^{16}$ 
Table S2. Steady-state parameters for Kemp eliminase variants with active site mutations ${ }^{\text {a }}$

\begin{tabular}{|c|c|c|c|}
\hline Variant & $\begin{array}{c}\boldsymbol{k}_{\text {cat }} \\
\left(\mathbf{s}^{-1}\right)\end{array}$ & $\begin{array}{c}\boldsymbol{K}_{\mathbf{M}} \\
(\boldsymbol{\mu M})\end{array}$ & $\begin{array}{c}\boldsymbol{k}_{\text {cat }} / \boldsymbol{K}_{\mathbf{M}} \\
\left(\mathbf{M}^{-1} \mathbf{s}^{-1}\right)\end{array}$ \\
\hline 1 A53-2.9 & $24 \pm 4$ & $590 \pm 130$ & $40900 \pm 8500$ \\
\hline C180S & $6.0 \pm 0.8$ & $650 \pm 70$ & $9200 \pm 1200$ \\
\hline C180A & $39 \pm 8$ & $1100 \pm 100$ & $36000 \pm 7300$ \\
\hline Y157F & $1.3 \pm 0.4$ & $340 \pm 110$ & $4100 \pm 1000$ \\
\hline Y157A & $1.1 \pm 0.1$ & $190 \pm 40$ & $6000 \pm 1100$ \\
\hline Y157F C180S & $0.3 \pm 0.1$ & $370 \pm 40$ & $700 \pm 200$ \\
\hline
\end{tabular}

${ }^{\text {a }}$ Measured at $25{ }^{\circ} \mathrm{C}$ in $50 \mathrm{mM}$ phosphate, $100 \mathrm{mM} \mathrm{NaCl}, 100 \mu \mathrm{M}$ TCEP, $10 \%$ methanol, $\mathrm{pH}$ 7.0.

b $1 \mathrm{~A} 53-2 \mathrm{Y} 157 \mathrm{~F}$ has a $\mathrm{p} K_{\mathrm{a}, 1}$ of $8.0 \pm 0.1$ and a $K_{\mathrm{a}, 2}$ of $9.2 \pm 0.1$.

Table S3. Kinetic parameters for selected artificial and natural enzymes that catalyze C-H deprotonation reactions

\begin{tabular}{|c|c|c|c|c|c|c|c|}
\hline & & catalyst & $\begin{array}{l}k_{\text {cat }} \\
{\left[\mathrm{s}^{-1}\right]}\end{array}$ & $\begin{array}{c}k_{\mathrm{cat}} / K_{\mathbf{M}} \\
{\left[\mathbf{M}^{-1} \mathbf{s}^{-1}\right]}\end{array}$ & $k_{\text {cat }} / k_{\text {uncat }}{ }^{\mathrm{b}}$ & $\begin{array}{l}1 / K_{\mathrm{TS}} \\
{\left[\mathbf{M}^{-1}\right]}\end{array}$ & Lit. \\
\hline \multirow{14}{*}{ 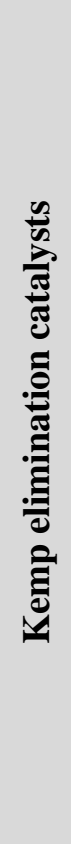 } & \multirow{2}{*}{$\begin{array}{l}\text { catalytic } \\
\text { antibodies }\end{array}$} & $4 \mathrm{~B} 2$ & 3.5 & $2.9 \times 10^{1}$ & $3.1 \times 10^{6}$ & $2.6 \times 10^{7}$ & 17 \\
\hline & & $34 \mathrm{E} 4$ & 0.66 & $5.5 \times 10^{3}$ & $5.9 \times 10^{5}$ & $4.9 \times 10^{9}$ & 18 \\
\hline & \multirow{7}{*}{$\begin{array}{c}\text { comp. } \\
\text { designed } \\
\text { enzymes }\end{array}$} & KE07 & 0.030 & $2.3 \times 10^{1}$ & $2.7 \times 10^{4}$ & $2.1 \times 10^{7}$ & 19 \\
\hline & & KE15 & 0.022 & $3.5 \times 10^{1}$ & $2.0 \times 10^{4}$ & $3.1 \times 10^{7}$ & 19 \\
\hline & & KE16 & 0.006 & $1.4 \times 10^{0}$ & $5.4 \times 10^{3}$ & $1.3 \times 10^{6}$ & 19 \\
\hline & & KE59 & 0.29 & $1.6 \times 10^{2}$ & $2.6 \times 10^{5}$ & $1.4 \times 10^{8}$ & 19 \\
\hline & & KE70 & 0.16 & $7.6 \times 10^{1}$ & $1.4 \times 10^{5}$ & $6.8 \times 10^{7}$ & 19 \\
\hline & & HG3 & 0.68 & $4.3 \times 10^{2}$ & $6.1 \times 10^{5}$ & $3.8 \times 10^{8}$ & 2 \\
\hline & & $1 \mathrm{~A} 53-2$ & 0.0058 & $4.9 \times 10^{0}$ & $1.1 \times 10^{4}$ & $1.3 \times 10^{6}$ & this work \\
\hline & \multirow{5}{*}{$\begin{array}{c}\text { evolved } \\
\text { enzymes }\end{array}$} & KE07 & 1.4 & $2.5 \times 10^{3}$ & $1.2 \times 10^{6}$ & $2.3 \times 10^{9}$ & 20 \\
\hline & & KE70 & 7.5 & $5.3 \times 10^{4}$ & $6.7 \times 10^{6}$ & $4.8 \times 10^{10}$ & 21 \\
\hline & & KE59.13 & 21.2 & $5.7 \times 10^{5}$ & $2.4 \times 10^{7}$ & $6.5 \times 10^{11}$ & 22 \\
\hline & & HG3.17 & 700 & $2.3 \times 10^{5}$ & $6.3 \times 10^{8}$ & $2.1 \times 10^{11}$ & 23 \\
\hline & & $1 \mathrm{~A} 53-2.9$ & 24 & $4.1 \times 10^{4}$ & $4.2 \times 10^{7}$ & $7.8 \times 10^{10}$ & this work \\
\hline \multirow{2}{*}{\multicolumn{2}{|c|}{ natural enzymes }} & TIM $^{\mathrm{a}}$ & 2000 & $4.0 \times 10^{8}$ & $2.6 \times 10^{10}$ & $5.3 \times 10^{15}$ & 24 \\
\hline & & $\mathrm{KSI}^{\mathrm{a}}$ & 86000 & $2.7 \times 10^{8}$ & $1.7 \times 10^{10}$ & $5.5 \times 10^{13}$ & 25 \\
\hline
\end{tabular}

${ }^{\mathrm{a}} \mathrm{TIM}=$ triosephosphate isomerase, $\mathrm{KSI}=$ ketosteroid isomerase. For TIM, kinetic parameters are stated for the reaction starting with glyceraldehyde-3-phosphate.

${ }^{\mathrm{b}}$ The second-order rate constant for the hydroxide-dependent reaction $\left(k_{\mathrm{HO}^{-}}\right)$was used to calculate the background rate constants $\left(k_{\text {uncat }}\right)$ for TIM and KSI according to $k_{\text {uncat }}=k_{\mathrm{HO}^{-}} \cdot \mathrm{c}\left(\mathrm{HO}^{-}\right)$, where $k_{\mathrm{HO}}$ is $0.24 \mathrm{M}^{-1} \mathrm{~s}^{-1}$ for triosephosphate isomerization ${ }^{26}$ and $49.2 \mathrm{M}^{-1} \mathrm{~s}^{-1}$ for $\Delta$-ketosteroid isomerization. ${ }^{27}$ The rate constants $\left(k_{\text {uncat }}\right)$ for background cleavage of 5-nitrobenzisoxazole ${ }^{28}$ 6-nitrobenzisoxazole and 5,7-dicyanobenzisoxazole ${ }^{22}$ are $1.12 \times 10^{-6} \mathrm{~s}^{-1}, 5.24 \times 10^{-7} \mathrm{~s}^{-1}$, and $8.82 \times 10^{-7} \mathrm{~s}^{-1}$, respectively. 
Table S4: Cloning primers for the directed evolution of 1A53-2

\begin{tabular}{|c|c|}
\hline \multicolumn{2}{|c|}{ Active site optimization: Rounds 1-5 } \\
\hline Name & Sequence 5'-3' \\
\hline 1A532_K53_NNK & GCTATCATTGCCGCGTATNNKCGTAAATCCCCGTCTGGTCTGG \\
\hline 1A532_K53_rev & ATACGCGGCAATGATAGC \\
\hline 1A532_S58_NNK & CGTATAAACGTAAATCCCCGNNKGGTCTGGATGTAGAACGTGATCC \\
\hline 1A532_L60_NNK & CGTATAAACGTAAATCCCCGTCTGGTNNKGATGTAGAACGTGATCCGATCG \\
\hline 1A532_S58/L60_rev & CGGGGATTTACGTTTATACG \\
\hline 1A532_A147_NNK & GTTCTTACGGCATGGAACCGNNKATTGTAATCAACGACGAAAATGACC \\
\hline 1A532_V149_NNK & GTTCTTACGGCATGGAACCGGCGATTNNKATCAACGACGAAAATGACC \\
\hline 1A532_A147/v149_rev & CGGTTCCATGCCGTAAGAAC \\
\hline 1A532 A180_NNK & GCTCGTTTCATCGAAATTNNKAGCCGCGATCTGGAAACTCTGG \\
\hline 1A532_R182_NNK & GCTCGTTTCATCGAAATTGCGAGCNNKGATCTGGAAACTCTGGAAATC \\
\hline 1A532_A180/R182_rev & AATTTCGATGAAACGAGC \\
\hline 1A532_Q211_NNK & GTTGTCAAAGTTGCGTGGNNKGGCATCTCTGAACGTAACG \\
\hline 1A532_Q211_rev & CCACGCAACTTTGACAAC \\
\hline L60_FP_wt & CGTATAAACGTAAATCCCCGTCTGGTCTGGATGTAGAACGTGATCCGATCG \\
\hline L60_FP_T & CGTATAAACGTAAATCCCCGTCTGGTACGGATGTAGAACGTGATCCGATCG \\
\hline A157_FP_wt & GTTCTTACGGCATGGAACCGGCGATTGTAATCAACGACGAAAATGACC \\
\hline A157_FP_FY & GTTCTTACGGCATGGAACCGTWTATTGTAATCAACGACGAAAATGACC \\
\hline A157_FP_W & GTTCTTACGGCATGGAACCGTGGATTGTAATCAACGACGAAAATGACC \\
\hline A157_FP_M & GTTCTTACGGCATGGAACCGATGATTGTAATCAACGACGAAAATGACC \\
\hline A180/R182_FP1 & $\begin{array}{l}\text { GCTCGTTTCATCGAAATTGCGAGCRKGGATCTGGAAACTCTGGAAATC } \\
\text {. }\end{array}$ \\
\hline A180/R182_FP2 & GCTCGTTTCATCGAAATTWSTAGCRKGGATCTGGAAACTCTGGAAATC \\
\hline Q211_FP_wt & CGTTGTCAAAGTTGCGTGGCAGGGCATCTCTGAACGTAACG \\
\hline Q211_FP_S & CGTTGTCAAAGTTGCGTGGTCGGGCATCTCTGAACGTAACG \\
\hline Q211_FP_G & CGTTGTCAAAGTTGCGTGGGGGGGCATCTCTGAACGTAACG \\
\hline 1A532_A51_NNK & GCAACATCACCGCTATCATTGCCNNKTATAAACGTAAATCCCCGTCTGG \\
\hline 1A532_A51_rev & GGCAATGATAGCGGTGATGTTGC \\
\hline 1A532_K53_NNK & GCTATCATTGCCGCGTATNNKCGTAAATCCCCGTCTGGTCTGG \\
\hline 1A532_S56_NNK & GCTATCATTGCCGCGTATAAACGTAAANNKCCGTCTGGTCTGGATGTAGAACG \\
\hline 1A532_K53_rev & ATACGCGGCAATGATAGC \\
\hline 1A532_S58_NNK & CGTATAAACGTAAATCCCCGNNKGGTCTGGATGTAGAACGTGATCC \\
\hline 1A532_S58/L60_rev & CGGGGATTTACGTTTATACG \\
\hline 1A532_A81_NNK & GGAACGTTACGCTGTAGGCCTGNNKATTGCGACCGAAGAAAAGTACTTTAACG \\
\hline 1A532_A83_NNK & GGAACGTTACGCTGTAGGCCTGGCGATTNNKACCGAAGAAAAGTACTTTAACG \\
\hline 1A532_A81_rev & CAGGCCTACAGCGTAACGTTCC \\
\hline 1A532_F89_NNK & CGATTGCGACCGAAGAAAAGTACNNKAACGGTAGCTACGAAACGCTGC \\
\hline 1A532_F89_rev & GTACTTTTCTTCGGTCGCAATCG \\
\hline 1A532_L108_NNK & GCTCTGTTAGCATTCCGATTNNKATGTGGGACTTTATCGTGAAAGAGTCC \\
\hline 1A532_W110_NNK & GCTCTGTTAGCATTCCGATTCTGATGNNKGACTTTATCGTGAAAGAGTCC \\
\hline 1A532_L108_rev & AATCGGAATGCTAACAGAGC \\
\hline 1A532_A131_NNK & CCTGGGTGCAGATACCGTCNNKCTGATTGTTAAAATCCTGACC \\
\hline 1A532_A131_rev & GACGGTATCTGCACCCAGG \\
\hline 1A532_L184_NNK & $\begin{array}{l}\text { GCTCGTTTCATCGAAATTTGTAGCCGCGATNNKGAAACTCTGGAAATCAACAAAG } \\
\end{array}$ \\
\hline 1A532_A180/R182_rev & AATTTCGATGAAACGAGC \\
\hline 1A532_W210_NNK & CCAACGTTGTCAAAGTTGCGNNKTCGGGCATCTCTGAACGTAACG \\
\hline 1A532_W210_rev & CGCAACTTTGACAACGTTGG \\
\hline
\end{tabular}


Table S4, continued: Cloning primers

\begin{tabular}{|c|c|}
\hline \multicolumn{2}{|c|}{ Global optimization: Rounds 6-9 } \\
\hline Name & Sequence 5'-3' \\
\hline 1A532_53/58_1 & GCTATCATTGCCGCGTATADGCGTAAATCCCCGKSGGGTCTGGATGTAGAACGTGATCC \\
\hline 1A532_53/58_2 & GCTATCATTGCCGCGTATSTTCGTAAATCCCCGKSGGGTCTGGATGTAGAACGTGATCC \\
\hline 1A532_53/58_3 & GCTATCATTGCCGCGTATCATCGTAAATCCCCGKSGGGTCTGGATGTAGAACGTGATCC \\
\hline 1A532_110_F & GCTCTGTTAGCATTCCGATTCTGATGTTTGACTTTAATCGTGAAAGAGTCC \\
\hline 1A532_110_WG & GCTCTGTTAGCATTCCGATTCTGATGKGGGACTTTATCGTGAAAGAGTCC \\
\hline 1A532_184_L & GCTCGTTTCATCGAAATTTGGTAGCCGCGATTTAGAAACTCTGGAAATCAACAAAG \\
\hline 1A532_184_F & GCTCGTTTCATCGAAATTTGTAGCCGCGATTTTGAAACTCTGGAAATCAACAAAG \\
\hline 1A532_210/211_1 & CCAACGTTGTCAAAGTTGCGKSGTCTGGCATCTCTGAACGTAACG \\
\hline 1A532_210/211_1 & CCAACGTTGTCAAAGTTGCGKSGTGCGGCATCTCTGAACGTAACG \\
\hline 1A532-1ib7-F1 & CTCTGCGTCGTCCGAGCTTCCRTGCCAGCCGTCAGCGCCCGATC \\
\hline 1A532-1ib7-R1 & GAAGCTCGGACGACGCAGAG \\
\hline $1 \mathrm{~A} 532-7 \mathrm{ib7-F2}$ & GCATTCTGGAATTCAACAAGCRCAACATCACCGCTATCAYTGCCGCGTATAGGCGTAAATCC \\
\hline 1A532-1ib7-R2 & CTTGTTGAATTCCAGAATGC \\
\hline $1 \mathrm{~A} 532-1 \mathrm{ib7-F3}$ & GGAAATCAACAAAGAAAACCAGMGCAAGCTGATCWCTATGATCCCGTCCAACGTTG \\
\hline $1 \mathrm{~A} 532-1 \mathrm{ib7-R3}$ & CTGGTTTTCTTTGTTGATTTCC \\
\hline 1A532-1ib7-F4 & TTGAAGAGCTGCGTAAACYGGGTGTGAACGCCTTCGGC \\
\hline $1 \mathrm{~A} 532-7 \mathrm{ib7-R4}$ & TTTACGCAGCTCTTCAA \\
\hline $1 \mathrm{~A} 532-7 \mathrm{ib7-F5}$ & AAAATCAAGGAGTTTATCSTGGGCAGCATCGAGGRTCGTGGTCACCATCACCACC \\
\hline 1A532-7ib7-R5 & CCTTGATTTTCTCCGGGTTGCKCATCAGGGAGGAGCYGATGCCGAAGGCGTTCACACC \\
\hline $1 \mathrm{~A} 532-7 \mathrm{ib} 9-\mathrm{F} 1$ & CAAGCGCAACATCACCGCTAYTATTGCCGCATATAGGCG \\
\hline 1A532-1ib9-R1 & CAAGCGCAACATCACCGCTA \\
\hline 1A532-1ib9-R1 & TAGCGGTGATGTTGCGCTTG \\
\hline $1 \mathrm{~A} 532-1 \mathrm{ib9}-\mathrm{F} 2$ & CGTCGCGCTGATTGTTAAARTCCTGACCGAACRTGAACTGGAAAGCCTGCTGG \\
\hline $1 \mathrm{~A} 532-1 \mathrm{ib} 9-\mathrm{R} 2$ & CGTCGCGCTGATTGTTAAA \\
\hline 1A532-1ib9-R2 & TTTAACAATCAGCGCGACG \\
\hline $1 \mathrm{~A} 532-1 \mathrm{ib9}-\mathrm{F} 3$ & GGGGCGGCATCTCTGAACGTAMCGAAMTTGAAGAGCTGCGTAAACYGGGTGTGAACGCCTTCGGC \\
\hline 1A532-1ib9-R3 & GGGGCGGCATCTCTGAACGTA \\
\hline $1 \mathrm{~A} 532-1 \mathrm{ib9}-\mathrm{R} 3$ & TACGTTCAGAGATGCCGCCCC \\
\hline 1A532-1ib9-F4 & GGAGAAAATCAAGGAGTTTATCSTGGGCAGCATCGAGGRTCGTGGTCAC \\
\hline 1A532-1ib9-R4 & GACAGCATCGAGGRTCGTGGTCACCRTCACCACCACCATTAGGGGATCCGGC \\
\hline $1 \mathrm{~A} 532-1 \mathrm{ib} 9-\mathrm{R} 4$ & GAGCCGGATCCCCTAATGGTGGTGGTGAYGGTGACCACGAYCCTCGATGCTG \\
\hline \multicolumn{2}{|c|}{ Site-directed mutagenesis } \\
\hline $1 \mathrm{~A} 10-178 \mathrm{Q}$ & CATCGGTGCTCGTTTCATCCAAATTTGTAGCCGCGATTTTG \\
\hline 1A10-178Q-rev & GATGAAACGAGCACCGATG \\
\hline $1 \mathrm{~A} 10-157 \mathrm{~A}$ & GTTCTTACGGCATGGAACCGGCTATTGTAATCAACGACGAAAATG \\
\hline $1 \mathrm{~A} 10-157 \mathrm{~A}-\mathrm{rev}$ & CGGTTCCATGCCGTAAGAAC \\
\hline $1 \mathrm{~A} 10-157 \mathrm{~F}$ & GTTCTTACGGCATGGAACCGTTTATTGTAATCAACGACGAAAATG \\
\hline 1A10-157F-rev & CGGTTCCATGCCGTAAGAAC \\
\hline 1A10-180A & GCTCGTTTCATCGAAATTGCTAGCCGCGATTTTGGAAACTC \\
\hline $1 \mathrm{~A} 10-180 \mathrm{~A}-\mathrm{rev}$ & AATTTCGATGAAACGAGC \\
\hline $1 \mathrm{~A} 10-180 \mathrm{~S}$ & GCTCGTTTCATCGAAATTTCTAGCCGCGATTTTTGAAACTC \\
\hline 1A10-180s-rev & AATTTCGATGAAACGAGC \\
\hline
\end{tabular}


Table S5: Data collection and refinement statistics for 1A53-2.5 (PDB ID: 6NW4).

\begin{tabular}{|c|c|}
\hline Data collection & \\
\hline Wavelength $(\AA)$ & 1.00 \\
\hline Space group & $\mathrm{P} 3{ }_{1} 21$ \\
\hline \multicolumn{2}{|l|}{ Cell dimensions } \\
\hline$a, b, c(\AA)$ & $61.304,61.304,121.278$ \\
\hline$\alpha, \beta, \gamma\left({ }^{\circ}\right)$ & $90,90,120$ \\
\hline Resolution range $(\AA)$ & $48.63-3.00(3.107-3.000)$ \\
\hline Total reflections & $54388(5338)$ \\
\hline Unique reflections & $5650(520)$ \\
\hline Multiplicity & $9.6(10.3)$ \\
\hline Completeness (\%) & $99.63(99.64)$ \\
\hline$<\mathrm{I} / \sigma \mathrm{I}>$ & $5.23(1.39)$ \\
\hline Wilson B-factor & 56.78 \\
\hline $\mathrm{R}_{\text {merge }}(\%)$ & $0.413(2.123)$ \\
\hline $\mathrm{R}_{\text {meas }}(\%)$ & $0.437(2.237)$ \\
\hline $\mathrm{R}_{\text {pim }}(\%)$ & $0.1417(0.708)$ \\
\hline $\mathrm{CC}_{1 / 2}(\%)$ & $0.994(0.724)$ \\
\hline $\mathrm{CC}^{*}(\%)$ & $0.998(0.917)$ \\
\hline \multicolumn{2}{|l|}{ Refinement } \\
\hline Reflections used for refinement & $5647(557)$ \\
\hline Reflections used for $\mathrm{R}_{\text {free }}$ & $296(27)$ \\
\hline $\mathrm{R}_{\text {work }}(\%)$ & $0.1870(0.3263)$ \\
\hline $\mathrm{R}_{\text {free }}(\%)$ & $0.2950(0.3343)$ \\
\hline $\mathrm{CC}$ (work) & $0.976(0.839)$ \\
\hline $\mathrm{CC}($ free $)$ & $0.886(0.869)$ \\
\hline Number of non-hydrogen atoms & 2058 \\
\hline Macromolecules & 2005 \\
\hline Ligands & 32 \\
\hline Solvent & 17 \\
\hline Protein residues & 247 \\
\hline \multicolumn{2}{|l|}{ R.m.s. deviations } \\
\hline Bonds $(\AA)$ & 0.015 \\
\hline Angles (deg) & 1.77 \\
\hline \multicolumn{2}{|l|}{ Ramachandran statistics (\%) } \\
\hline Favored $(\%)$ & 93.88 \\
\hline Allowed (\%) & 6.12 \\
\hline Outliers (\%) & 0.00 \\
\hline Rotamer outliers (\%) & 10.50 \\
\hline Clash score & 9.77 \\
\hline Average B-factors $\left(\AA^{2}\right)$ & 64.52 \\
\hline Macromolecules & 64.39 \\
\hline Ligands & 88.51 \\
\hline Water & 40.62 \\
\hline
\end{tabular}

*Values in parentheses are for highest-resolution shell. 


\section{Supplementary Figures}

1A53-2:

MPRYLKGWLK DVVQLSLRRP SFRASRQRPI ISLNERILEF NKRNITAIIA AYKRKSPSGP

DVERDPIEYS KFMERYAVGL AIATEEKYFN GSYETLRKIA SSVSIPILMW DFIVKESQID

DAYNLGADTV ALIVKILTER ELESLLEYAR SYGMEPAIVI NDENDLDIAL RIGARFIEIA

SRDLETLEIN KENQRKLISM IPSNVVKVAW QGISERNEIE ELRKLGVNAF GIGSSLMRNP

EKIKEFILGS IEGRGHHHHH $\mathrm{H}$

1A53-2.5: $\quad$ 1A53-2 K53R S58C A157Y A180C L184F Q211S

1A53-2.9: 1A53-2.5 R23H I48T I82V I219L M237L R238S L248V G253D H257R

Figure S1. Amino acid sequences of 1A53-2.9. The catalytic base (Glu178, yellow), as well as mutations introduced during design (gray), active site optimization (green), and global optimization (blue) are highlighted. 
1A53-2

$k_{\text {cat }}=0.0058 \pm 0.0004 \mathrm{~s}^{-1} ; k_{\text {cat }} / K_{\mathrm{M}}=4.9 \pm 0.7 \mathrm{M}^{-1} \mathrm{~s}^{-1}$

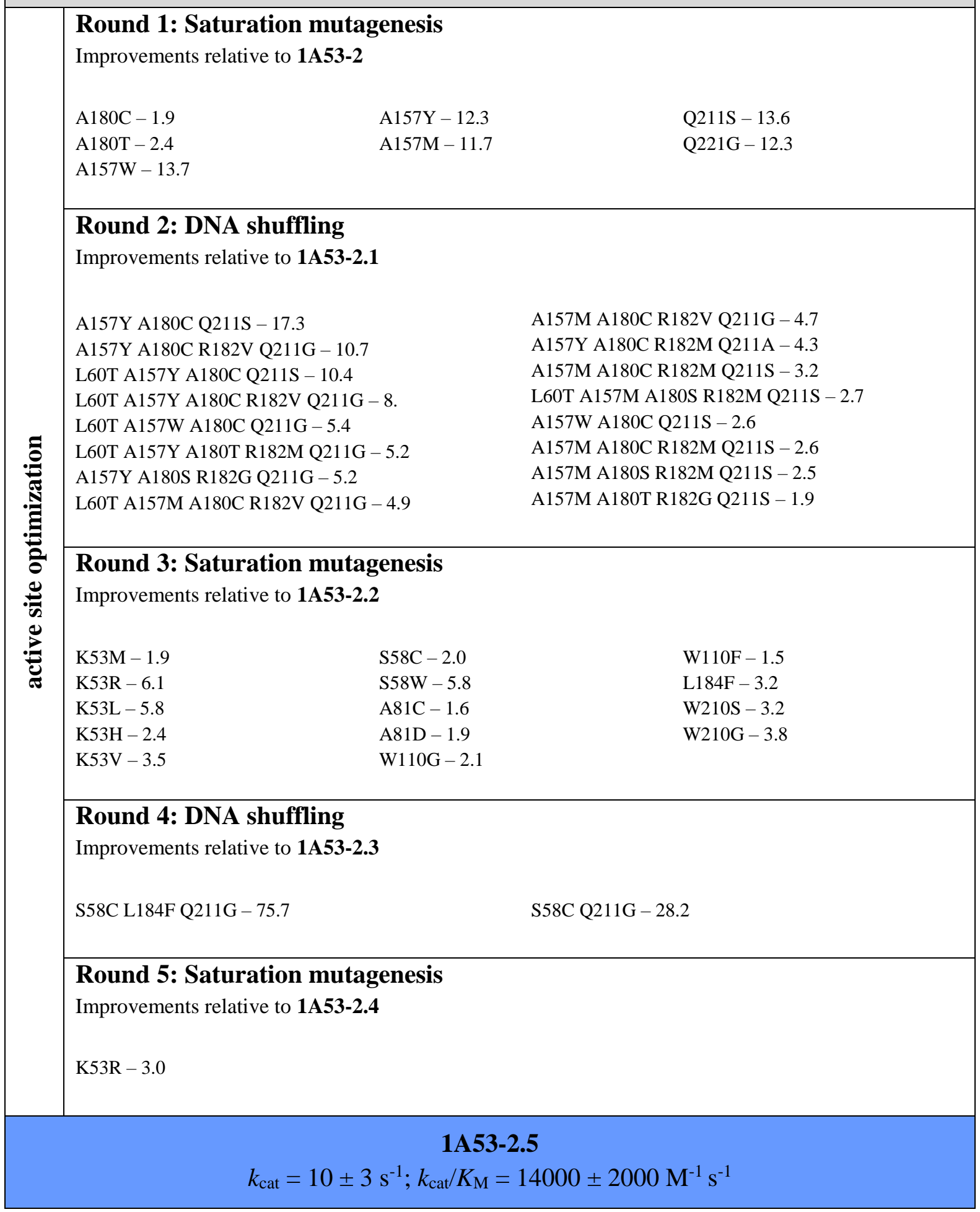

Figure S2. Active site optimization of 1A53-2. Activity was assayed with whole cells in 96well plates and is thus not corrected for enzyme concentration. The specific variants are:

1A53-2.1: 1 A 53-2 A157W

1A53-2.3: $\quad$ 1A53-2 A157Y A180C Q211S

1A53-2.4: $\quad$ 1A53-2 S58C A157Y A180C L184F Q211S

1A53-2.5: $\quad$ 1A53-2 K53R S58C A157Y A180C L184F Q211S 


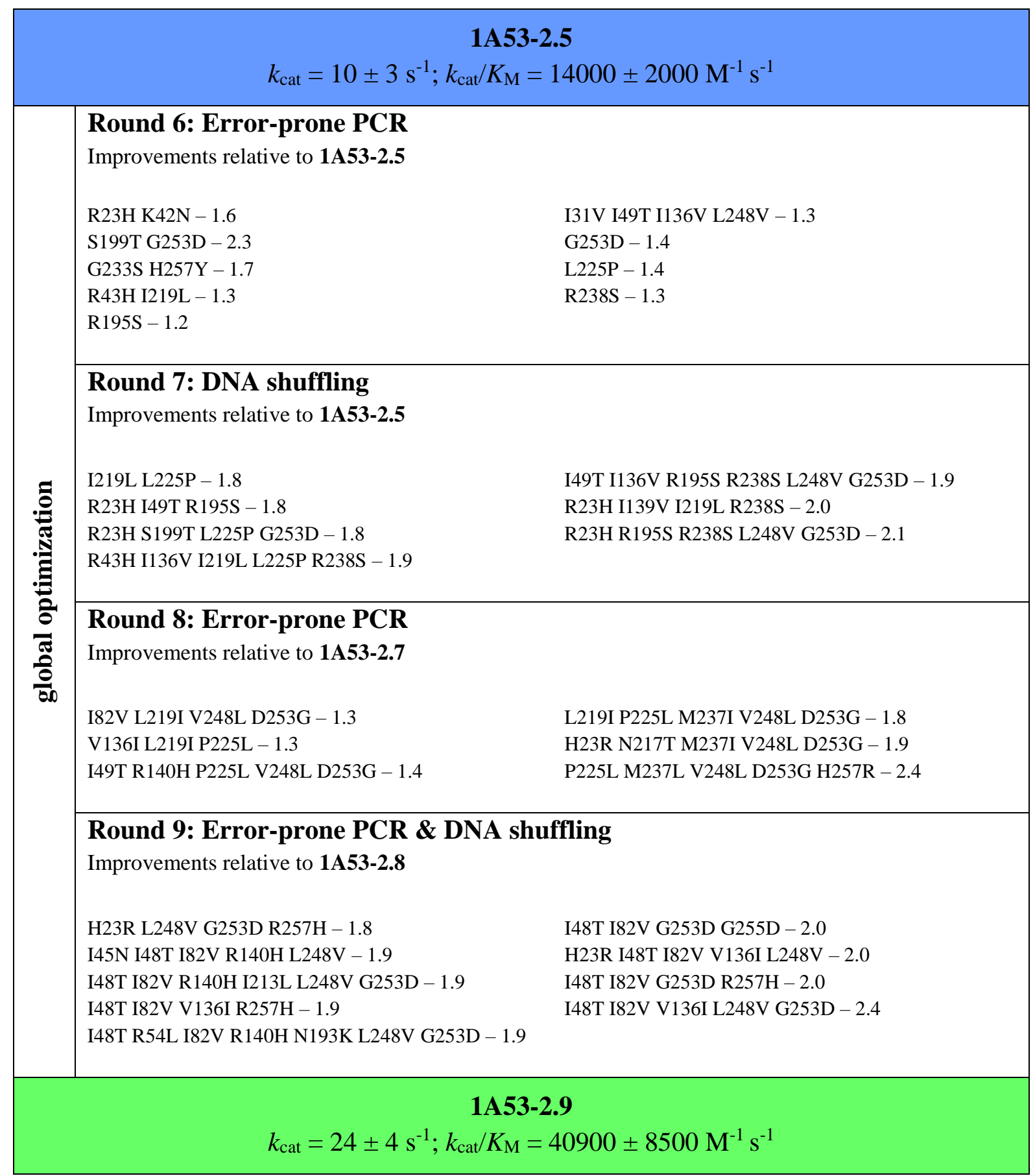

Figure S3. Global optimization of 1A53-2. Activity was assayed with whole cells in 96-well plates and is thus not corrected for enzyme concentration. The specific variants are:

1A53-2.5: 1 A53-2 K53R S58C A157Y A180C L184F Q211S

1A53-2.7: 1A53-2.5 R23H I136V I219L R238S

1A53-2.8: 1A53-2.5 R23H I136V I219L M237L R238S H257R

1A53-2.9: $\quad$ 1A53-2.5 R23H I48T I82V I219L M237 R238S L248V G253D H257R 

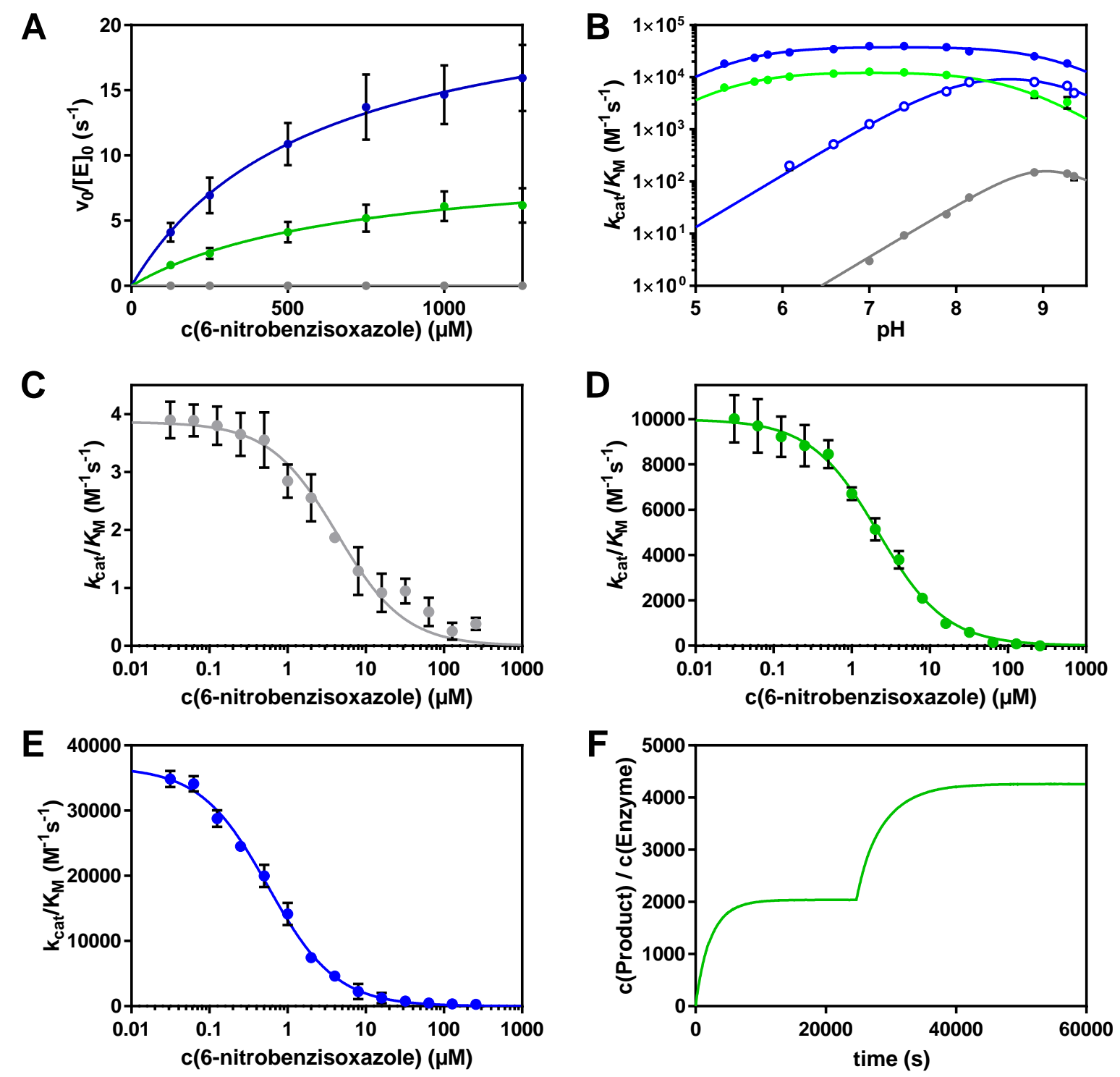

Figure S4. Biochemical characterization of 1A53-2 (gray), 1A53-2.5 (green) and 1A53-2.9 (blue). (A) Michaelis-Menten kinetics show that improvements during evolution are mainly due to increases in $k_{\text {cat }}$ (B) The $\mathrm{pH}$ optimum for the evolved variants is substantially broader than for the computationally designed enzyme, owing to a decrease in $\mathrm{p} K_{\mathrm{a} 1}$ from $8.7 \pm 0.3$ to $5.4 \pm 0.1$. Knock-out studies indicate that Tyr157, which was introduced during evolution, is responsible for this decrease; replacement of this residue with a phenylalanine (1A53-2.9 Y157F, blue open circles) increased $\mathrm{p} K_{\mathrm{a} 1}$ to $8.0 \pm 0.1$. (C-E) The affinity of the Kemp eliminase variants for the competitive inhibitor 5-nitrobenzotriazole increases with improvements in activity from $1.8 \pm 0.2$ $\mu \mathrm{M}$ for $1 \mathrm{~A} 53-2$ to $0.46 \pm 0.07 \mu \mathrm{M}$ for $1 \mathrm{~A} 53-2.5$ and $0.23 \pm 0.02 \mu \mathrm{M}$ for $1 \mathrm{~A} 53-2.9$. (F) Kemp eliminase 1A53-2.5 can perform at least 4000 turnovers (background product formation was subtracted from the depicted graph as described in the methods section). 


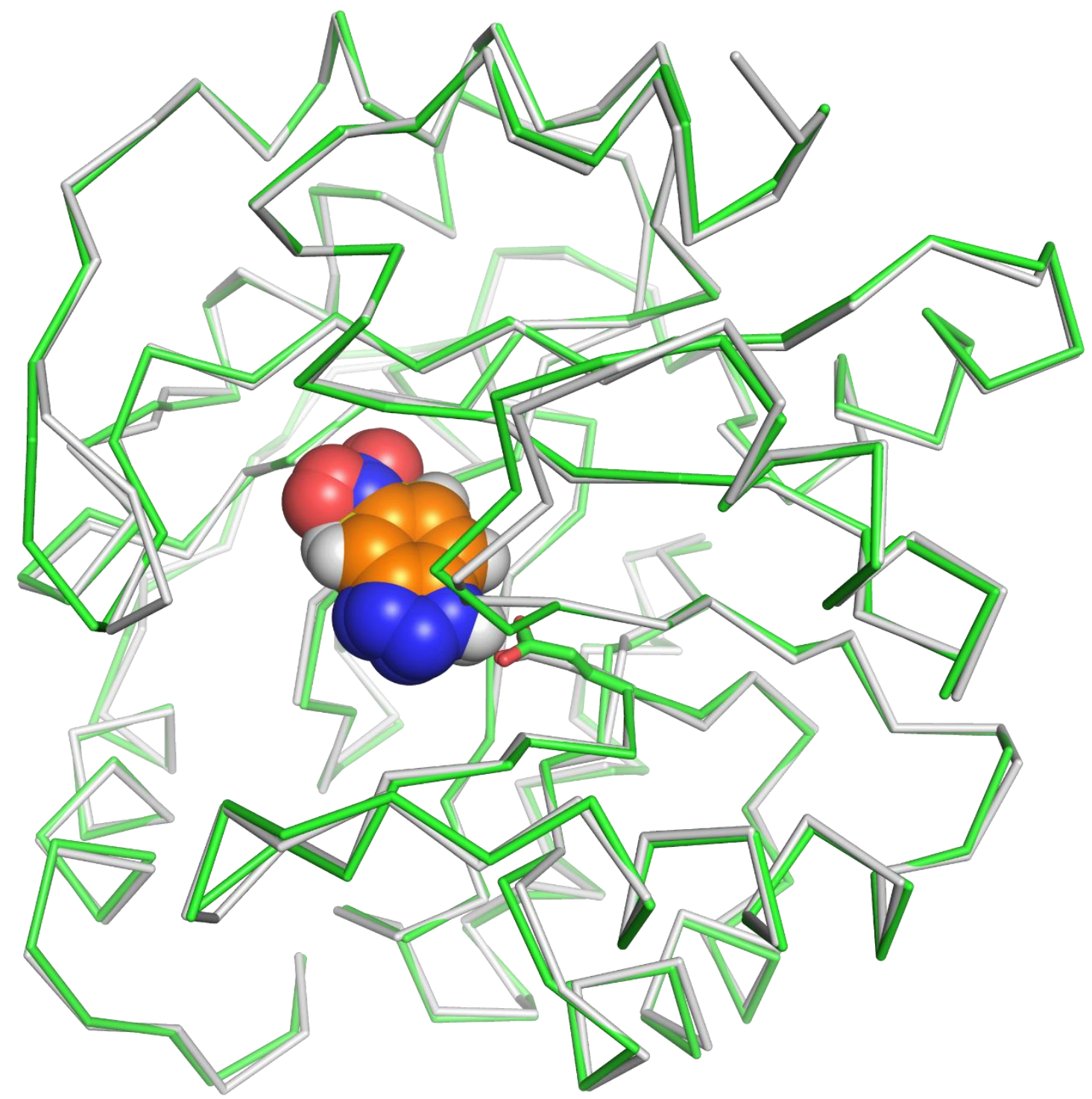

Figure S5. Structural alignment of 1A53-2 (gray) and 1A53-2.5 (green). The 5-nitrobenzotriazole inhibitor is depicted in orange. 1A53-2 and 1A53-2.5 have very similar overall structures and differ primarily at their respective active sites. Only a few solvent exposed loops adopt slightly different conformations. 

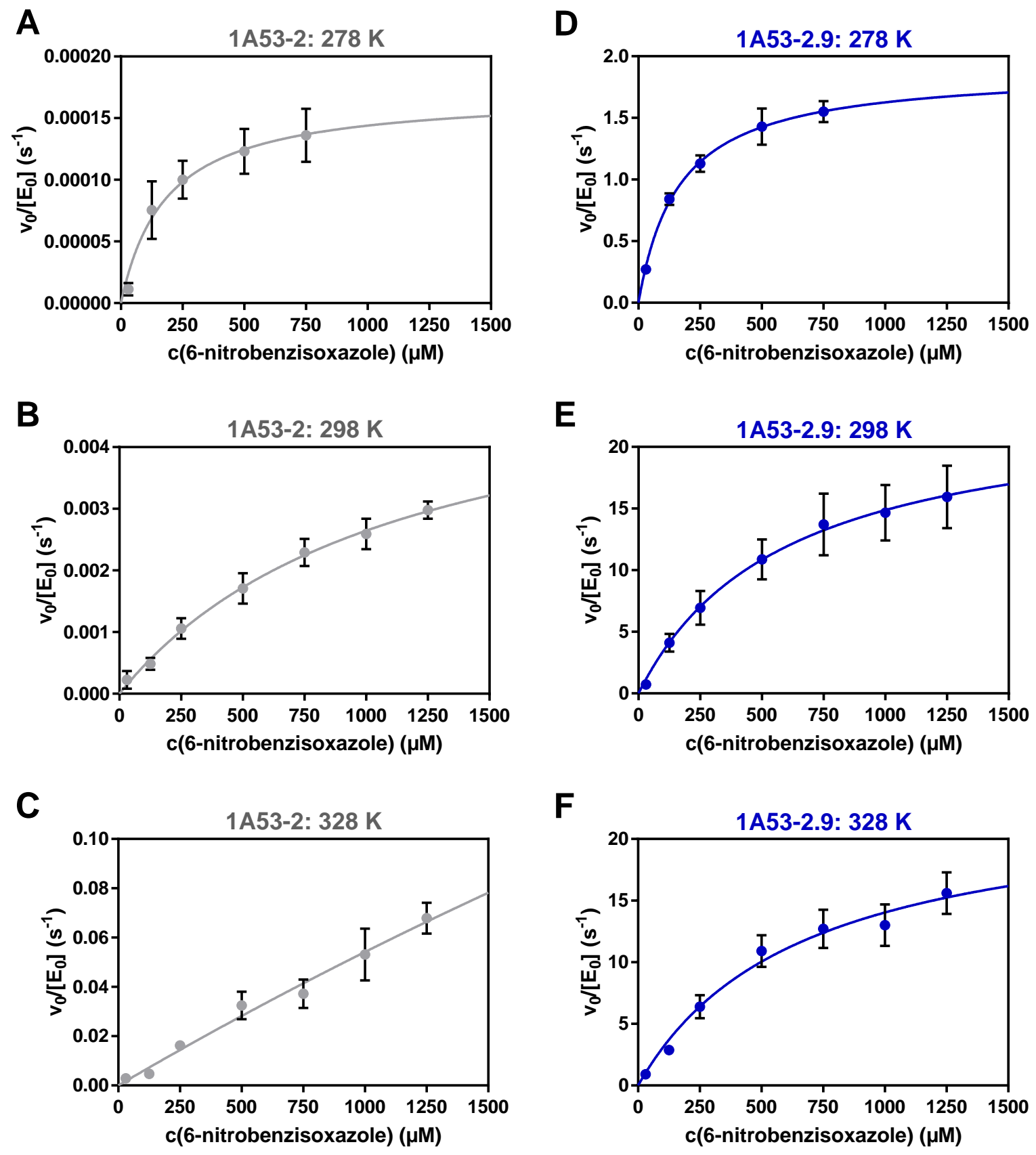

Figure S6. Temperature dependent Michaelis-Menten kinetics. (A-C) The starting design $1 \mathrm{~A} 53-2$ was assayed at $278 \mathrm{~K}, 298 \mathrm{~K}$, and $328 \mathrm{~K}$. At $278 \mathrm{~K}, k_{\text {cat }}=0.00017 \pm 0.00002$ $\mathrm{s}^{-1}, K_{\mathrm{M}}=180 \pm 50 \mu \mathrm{M}$; at $298 \mathrm{~K}, k_{\mathrm{cat}}=0.0058 \pm 0.0008 \mathrm{~s}^{-1}, K_{\mathrm{M}}=1200 \pm 300 \mu \mathrm{M}$. At $328 \mathrm{~K}$, saturation was not observed below $1.25 \mathrm{mM}$ 6-nitrobenziosoxazole. Although $k_{\text {cat }}$ cannot be accurately determined, it is $>20$-fold larger than $k_{\text {cat }}$ at $298 \mathrm{~K}$ as judged from $\mathrm{v}_{0} /\left[\mathrm{E}_{0}\right]$ at $1.25 \mathrm{mM}$ 6-nitrobenziosoxazole. In contrast, the apparent second-order rate constant $k_{\text {cat }} / K_{\mathrm{M}}$ can be determined accurately from the data collected at substrate concentrations below $K_{\mathrm{M}}$. At 328 $\mathrm{K}, k_{\text {cat }} / K_{\mathrm{M}}=58 \pm 5 \mathrm{M}^{-1} \mathrm{~s}^{-1}$. (D-F) The evolved variant 1A53-2.9 shows saturation behavior at all three temperatures. At $278 \mathrm{~K}, k_{\text {cat }}=1.9 \pm 0.1 \mathrm{~s}^{-1}, K_{\mathrm{M}}=160 \pm 10 \mu \mathrm{M}$; at $298 \mathrm{~K}, k_{\text {cat }}=24 \pm 2$ $\mathrm{s}^{-1}, K_{\mathrm{M}}=590 \pm 80 \mu \mathrm{M}$; at $328 \mathrm{~K}, k_{\mathrm{cat}}=23 \pm 3 \mathrm{~s}^{-1}, K_{\mathrm{M}}=660 \pm 150 \mu \mathrm{M}$. Note that in contrast to $1 \mathrm{~A} 53-2$ neither $k_{\text {cat }}$ nor $k_{\text {cat }} / K_{\mathrm{M}}$ increase monotonically above $298 \mathrm{~K}$. 
A

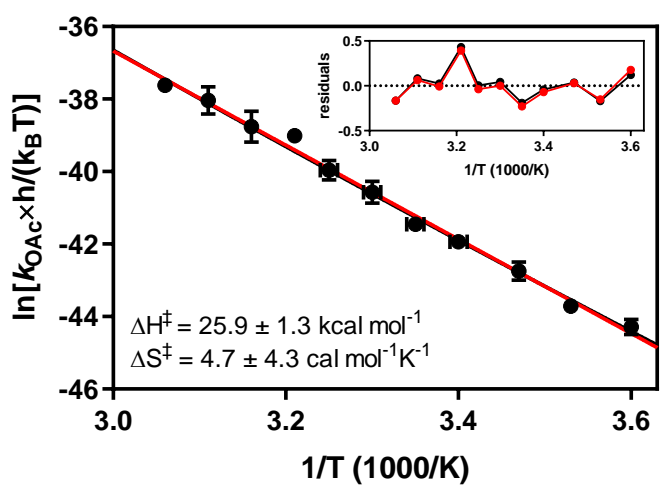

C

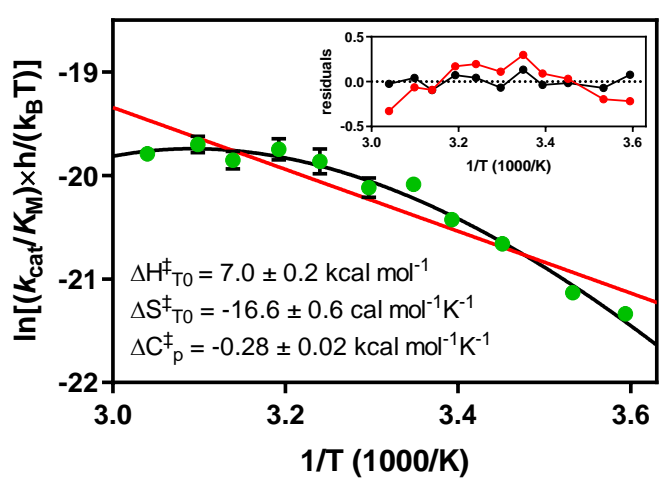

B

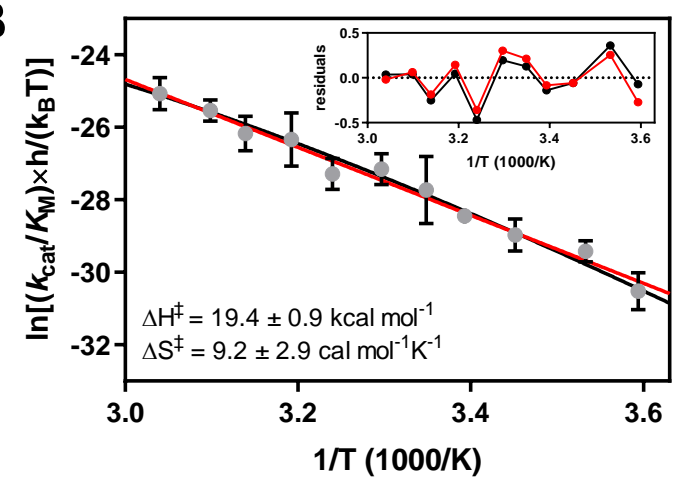

D

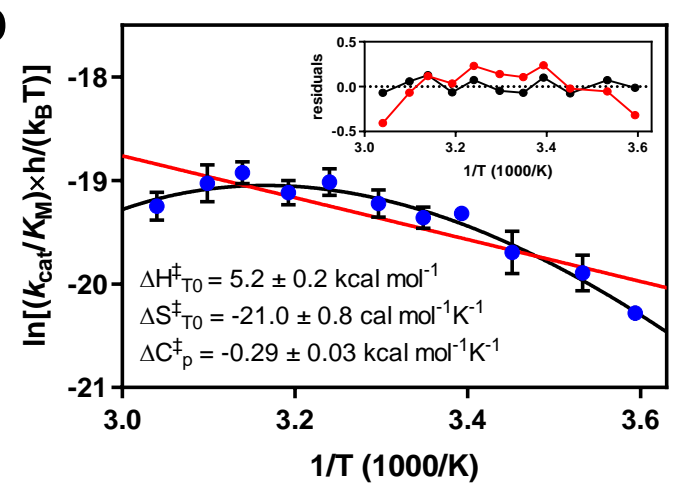

Figure S7. Temperature dependence of the Kemp elimination. (A and B) Eyring plots of the acetate (black) and 1A53-2 (gray) reactions. The data were fitted to the standard Eyring equation, $\ln \left[\left(k_{\mathrm{cat}} / K_{\mathrm{M}}\right) \cdot\left(\mathrm{h} / k_{\mathrm{B}} \mathrm{T}\right)\right]=-\Delta \mathrm{H}^{\ddagger} / \mathrm{RT}+\Delta \mathrm{S}^{\ddagger} / \mathrm{R}$, and do not show statistically significant curvature (Student's t-test comparing both models gives $\mathrm{p}=0.1433$ for $1 \mathrm{~A} 53-2)$ and the residuals (inset) are normally distributed. (C and D) The Eyring plots for Kemp eliminases 1A53-2.5 (green) and 1A53-2.9 (blue) show pronounced curvature. Fitting to the standard Eyring equation (red) reveals systematic deviations from linearity based on the residuals (inset, red). Fitting the data to equation 1 in the main text (black) provides substantially improved fits and gives statistically significant heat capacities $(\mathrm{p}<0.0001)$. 


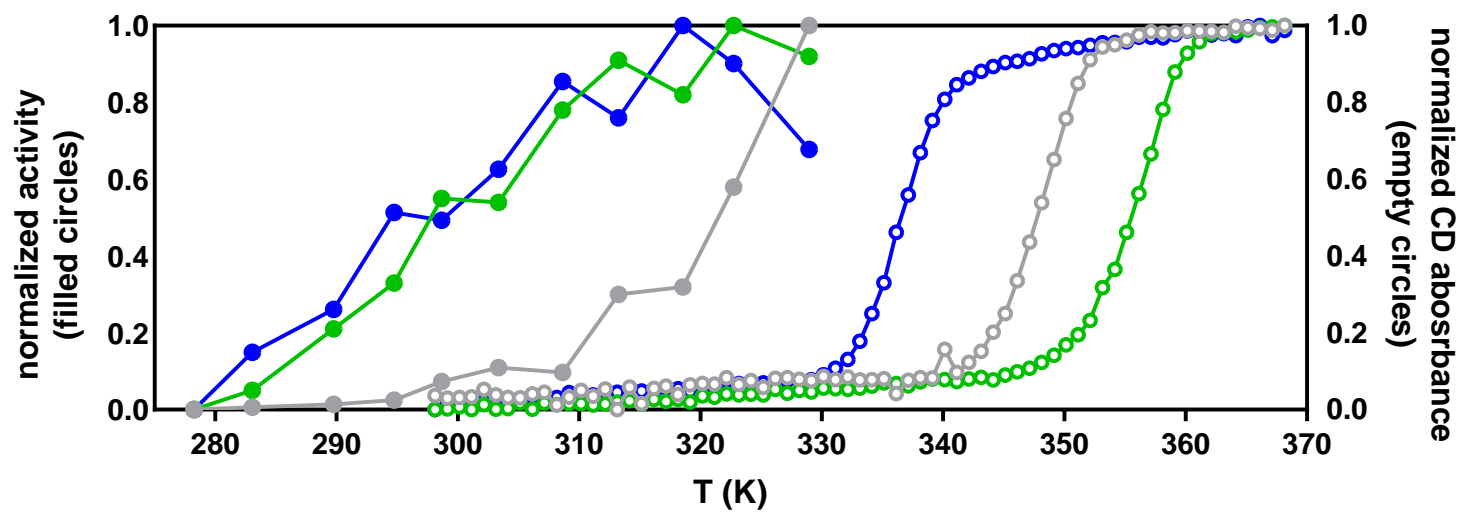

Figure S8. Kemp eliminase activity and structural integrity as a function of temperature. 1A53-2 (gray), 1A53-2.5 (green) and 1A53-2.9 (blue) denature (open circles) at temperatures substantially higher than their optimal temperature (filled circles). The data were normalized to their maximum and minimum values to facilitate comparison of the different variants. 
A

1A53-2
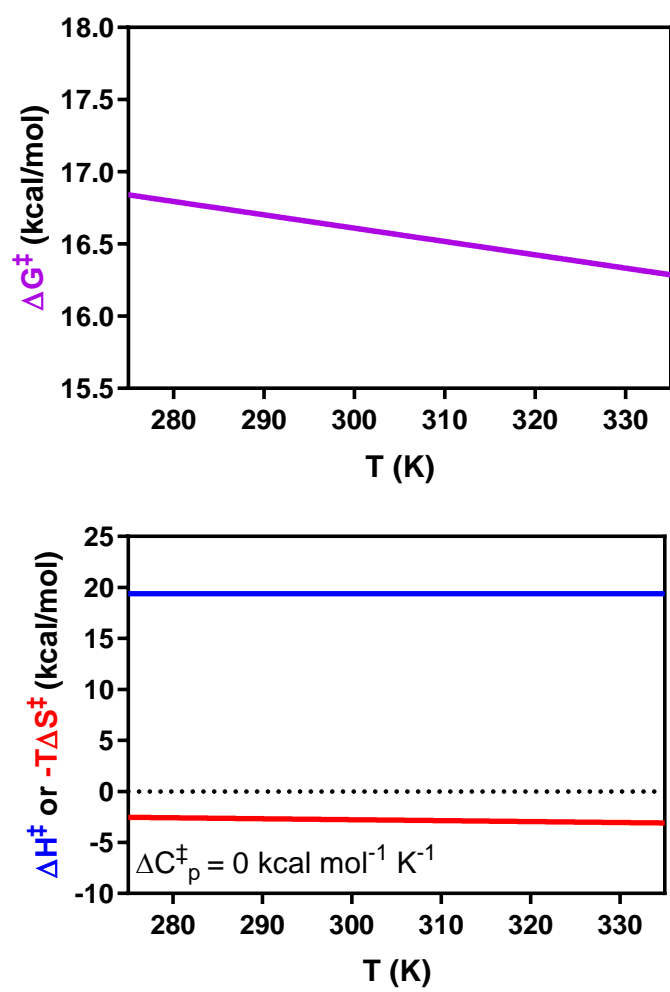

B
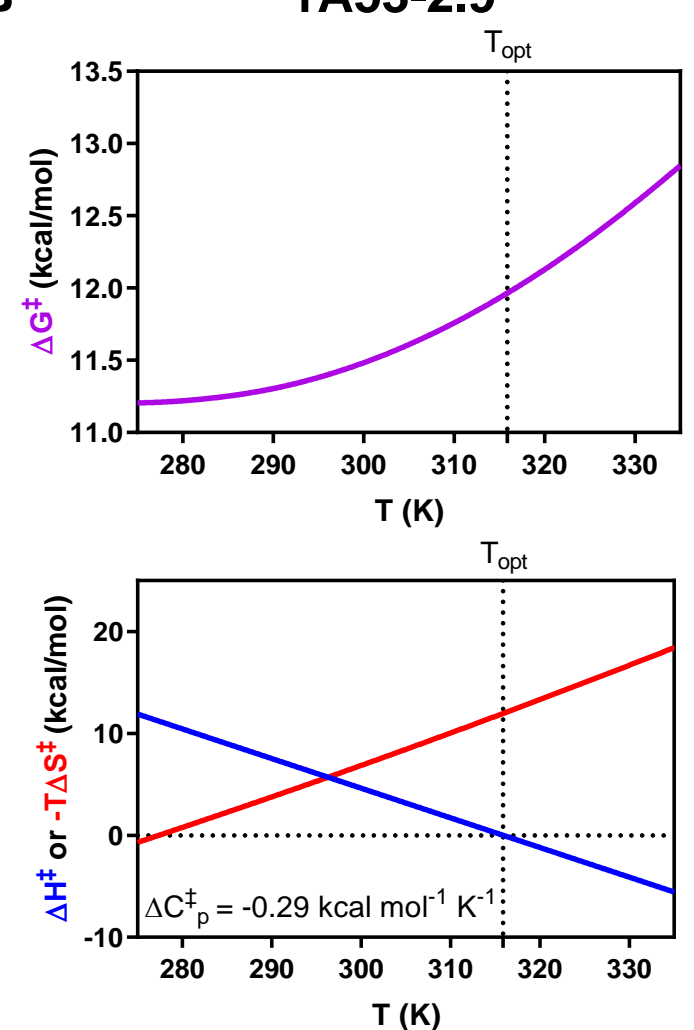

Figure S9. Temperature dependence of $\Delta \mathrm{H}^{\ddagger}$ (blue), $-\mathrm{T} \Delta \mathrm{S}^{\ddagger}$ (red) and $\Delta \mathrm{G}^{\ddagger}$ (purple). (A) The designed Kemp eliminase 1A53-2 has a linear Eyring plot $\left(\Delta \mathrm{C}_{\mathrm{p}}^{\ddagger}=0\right)$, so $\Delta \mathrm{H}^{\ddagger}$ (blue) is temperature independent. This term dominates $\Delta \mathrm{G}^{\ddagger}$ for the reaction across the entire temperature range. (B) The most evolved variant, $1 \mathrm{~A} 53-2.9$, has a $\Delta \mathrm{C}_{\mathrm{p}}^{\ddagger}$ of $-0.29 \mathrm{kcal} \mathrm{mol}^{-1} \mathrm{~K}^{-1}$, resulting in temperaturedependent $\Delta \mathrm{H}^{\ddagger}$ values. As a result, $\Delta \mathrm{G}^{\ddagger}$ exhibits pronounced curvature. At $298 \mathrm{~K}$, where evolution was performed, $\Delta \mathrm{H}^{\ddagger}$ and $-\mathrm{T} \Delta \mathrm{S}^{\ddagger}$ contribute nearly equally to the energy barrier for reaction. At temperatures below $298 \mathrm{~K}$, the enthalpic term dominates, whereas the $\Delta S^{\ddagger}$ term becomes increasingly important at higher temperatures. 


\section{References}

(1) Iranpoor, N.; Firouzabadi, H.; Nowrouzi, N., A novel method for the highly efficient synthesis of 1,2-benzisoxazoles under neutral conditions using the Ph3P/DDQ system. Tetrahedron Lett. 2006, 47, 8247-8250.

(2) Privett, H. K.; Kiss, G.; Lee, T. M.; Blomberg, R.; Chica, R. A.; Thomas, L. M.; Hilvert, D.; Houk, K. N.; Mayo, S. L., Iterative approach to computational enzyme design. Proc. Natl. Acad. Sci. U. S. A. 2012, 109, 3790-3795.

(3) Hennig, M.; Darimont, B. D.; Jansonius, J. N.; Kirschner, K., The catalytic mechanism of indole-3-glycerol phosphate synthase: crystal structures of complexes of the enzyme from Sulfolobus solfataricus with substrate analogue, substrate, and product. J. Mol. Biol. 2002, 319, 757-766.

(4) Sambrook, J.; Russell, D. W., Molecular Cloning: A Laboratory Manual. . Quart. Rev. Biol. 2001, 76, 348-349.

(5) Higuchi, R.; Krummel, B.; Saiki, R. K., A general method of in vitro preparation and specific mutagenesis of DNA fragments: study of protein and DNA interactions. Nucleic Acids Res. 1988, 16, 7351-7367.

(6) Reetz, M. T.; Kahakeaw, D.; Lohmer, R., Addressing the numbers problem in directed evolution. ChemBioChem 2008, 9, 1797-1804.

(7) Gasteiger, E.; Hoogland, C.; Gattiker, A.; Duvaud, S.; Wilkins, M. R.; Appel, R. D.; Bairoch, A., Protein identification and analysis tools on the ExPASy server. John M. Walker (ed): The Proteomics Protocols Handbook, Humana Press 2005, 571-607

(8) Hu, Y.; Houk, K. N.; Kikuchi, K.; Hotta, K.; Hilvert, D., Nonspecific medium effects versus specific group positioning in the antibody and albumin catalysis of the base-promoted ring-opening reactions of benzisoxazoles. J. Am. Chem. Soc. 2004, 126, 8197-8205.

(9) Evans, M. G.; Polanyi, M., Some applications of the transition state method to the calculation of reaction velocities, especially in solution. Trans. Faraday. Soc. 1935, 31, 875894.

(10) Kabsch, W., XDS. Acta Crystallogr. D 2010, 66, 125-132. 
(11) McCoy, A. J.; Grosse-Kunstleve, R. W.; Adams, P. D.; Winn, M. D.; Storoni, L. C.; Read, R. J., Phaser crystallographic software. J. Appl. Crystallogr. 2007, 40, 658-674.

(12) Emsley, P.; Cowtan, K., Coot: model-building tools for molecular graphics. Acta Crystallogr. D 2004, 60, 2126-2132.

(13) Afonine, P. V.; Grosse-Kunstleve, R. W.; Echols, N.; Headd, J. J.; Moriarty, N. W.; Mustyakimov, M.; Terwilliger, T. C.; Urzhumtsev, A.; Zwart, P. H.; Adams, P. D., Towards automated crystallographic structure refinement with phenix.refine. Acta Crystallogr. D 2012, $68,352-367$.

(14) Bricogne, G.; Blanc, E.; Brandl, M.; Flensburg, C.; Keller, P.; Paciorek, W.; Roversi, P.; Sharff, A.; Smart, O.; Vonrhein, C.; Womack, T., BUSTER version 2.10.3 Cambridge, United Kingdom: Global Phasing Ltd 2017.

(15) Radzicka, A.; Wolfenden, R., A proficient enzyme. Science 1995, 267, 90-93.

(16) Arcus, V. L.; Prentice, E. J.; Hobbs, J. K.; Mulholland, A. J.; Van der Kamp, M. W.; Pudney, C. R.; Parker, E. J.; Schipper, L. A., On the temperature dependence of enzymecatalyzed rates. Biochemistry 2016, 55, 1681-1688.

(17) Genre-Grandpierre, A.; Tellier, C.; Loirat, M.-J.; Blanchard, D.; Hodgson, D. R. W.; Hollfelder, F.; Kirby, A. J., Catalysis of the Kemp elimination by antibodies elicited against a cationic hapten. Bioorg. Med. Chem. Lett. 1997, 7, 2497-2502.

(18) Thorn, S. N.; Daniels, R. G.; Auditor, M.-T. M.; Hilvert, D., Large rate accelerations in antibody catalysis by strategic use of haptenic charge. Nature 1995, 373, 228-230.

(19) Röthlisberger, D.; Khersonsky, O.; Wollacott, A. M.; Jiang, L.; DeChancie, J.; Betker, J.; Gallaher, J. L.; Althoff, E. A.; Zanghellini, A.; Dym, O.; Albeck, S.; Houk, K. N.; Tawfik, D. S.; Baker, D., Kemp elimination catalysts by computational enzyme design. Nature 2008, 453, 190-195.

(20) Khersonsky, O.; Röthlisberger, D.; Dym, O.; Albeck, S.; Jackson, C. J.; Baker, D.; Tawfik, D. S., Evolutionary optimization of computationally designed enzymes: Kemp eliminases of the KE07 series. J. Mol. Biol. 2010, 396, 1025-1042.

(21) Khersonsky, O.; Röthlisberger, D.; Wollacott, A. M.; Murphy, P.; Dym, O.; Albeck, S.; Kiss, G.; Houk, K. N.; Baker, D.; Tawfik, D. S., Optimization of the in-silico-designed 
kemp eliminase KE70 by computational design and directed evolution. J. Mol. Biol. 2011, 407, 391-412.

(22) Khersonsky, O.; Kiss, G.; Röthlisberger, D.; Dym, O.; Albeck, S.; Houk, K. N.; Baker, D.; Tawfik, D. S., Bridging the gaps in design methodologies by evolutionary optimization of the stability and proficiency of designed Kemp eliminase KE59. Proc. Natl. Acad. Sci. U. S. A. 2012, 109, 10358-10363.

(23) Blomberg, R.; Kries, H.; Pinkas, D. M.; Mittl, P. R.; Grütter, M. G.; Privett, H. K.; Mayo, S. L.; Hilvert, D., Precision is essential for efficient catalysis in an evolved Kemp eliminase. Nature 2013, 503, 418-421.

(24) Knowles, J. R.; Albery, W. J., Perfection in enzyme catalysis: The energetics of triosephosphate isomerase. Acc. Chem. Res. 1977, 10, 105-111.

(25) Hawkinson, D. C.; Eames, T. C.; Pollack, R. M., Energetics of 3-oxo-delta 5-steroid isomerase: source of the catalytic power of the enzyme. Biochemistry 1991, 30, 10849-10858.

(26) Richard, J. P., Acid-base catalysis of the elimination and isomerization reactions of triose phosphates. J. Am. Chem. Soc. 1984, 106, 4926-4936.

(27) Houck, W. J.; Pollack, R. M., Activation enthalpies and entropies for the microscopic rate constants of acetate-catalyzed isomerization of 5-androstene-3,17-dione. J. Am. Chem. Soc. 2003, 125, 10206-10212.

(28) Casey, M. L.; Kemp, D. S.; Paul, K. G.; Cox, D. D., Physical organic chemistry of benzisoxazoles. I. Mechanism of the base-catalyzed decomposition of benzisoxazoles. J. Org. Chem. 1973, 38, 2294-2301. 